*aMIS View/Print Document Cover Sheet

This document was retrieved from the Boeing ISEARCH System.

Accession \#: D196054914

Document \#: SD-WM-ER-506

Title/Desc:

TANK 241AX102 HEADSPACE GAS \& VAPOR

CHARACTERIZATION RESULTS FOR SAMPLES COLLECTED IN $6 / 1995$ 


\begin{tabular}{|l|l|}
\hline $\begin{array}{l}\text { 2. To: (Receiving organization) } \\
\text { DISTRIBUTION }\end{array}$ & $\begin{array}{l}\text { 3. From: Coriginating organization) } \\
\text { TWRS/CHARACTERIZATION PROJECT }\end{array}$ \\
\hline 5. Proj./Prog./Dept./Div.: & $\begin{array}{l}\text { 6. Cog. Engr.: } \\
\text { TWRS/CHAR PROJECT }\end{array}$ \\
\hline
\end{tabular}

8. Originator Remarks:

N/A
4. Related EDT No.:

N/A

7. Purchase Order No.: N/A

9. Equip./Component No.: $N / A$

10. System/Bldg./Facility: 2704HV/200E

11. Receiver Remarks:

12. Major Assm. Dwg. No.: N/A

13. Permit/Permit Application No.: $N / A$

14. Required Response Date: $09 / 27 / 95$

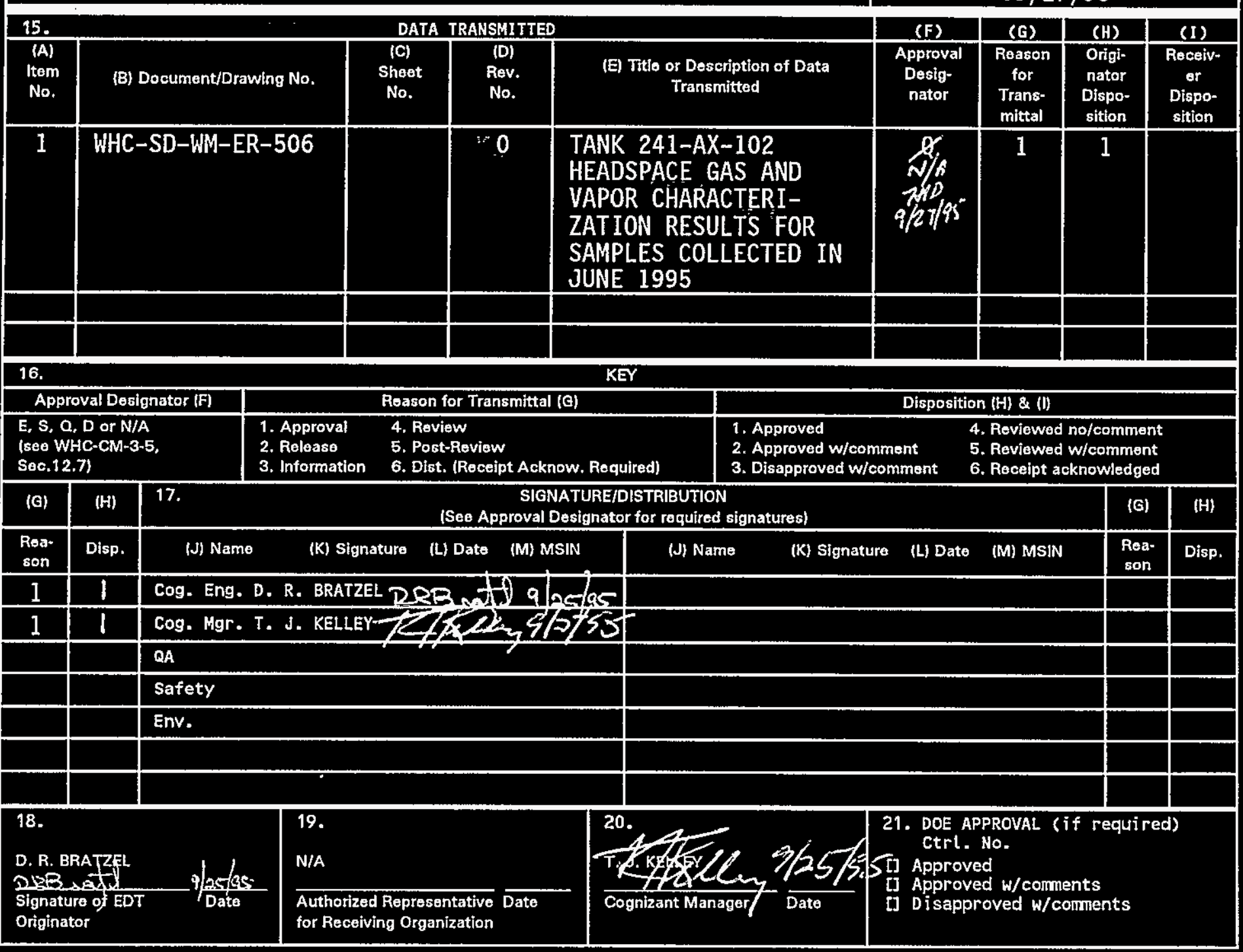

BD-7400-172-2 (04/94) GEF097 
THIS PAGE INTENTIONAITI
LETT BLANT 


\section{RELEASE AUTHORIZATION}

\begin{tabular}{|l|l|}
\hline Document Number: & WHC-SD-WM-ER-506, REV 0 \\
\hline Document Title: & $\begin{array}{l}\text { Tank 241-AX-102 Headspace Gas and Vapor } \\
\text { Characterization Results for Samples Collected in } \\
\text { June 1995 }\end{array}$ \\
\hline Release Date: $\quad 9 / 28 / 95$ \\
\hline $\begin{array}{c}\text { This document was reviewed following the } \\
\text { procedures described in WHC-CM-3-4 and is: }\end{array}$ \\
APPROVED FOR PUBLIC RELEASE \\
WHC Information Release Administration Specialist: \\
Kara Broz \\
\hline
\end{tabular}

TRADEMARK DISCLATHER. Reference here in to any specific commercial product, process, or service by trade name, trademark, manufacturer, or otherwise, does not necessarily constitute or imply its endorsement, recommendation, or favoring by the United States Government or any agency thereof or its contractors or subcontractors.

This report has been reproduced from the best available copy. Available in paper copy. Printed in the United States of America. To obtain copies of this report, contact:

Westinghouse Hanford Company - Document Control Services

P.0. Box 1970, Mailstop H6-08, Richland, WA 99352

Telephone: (509) 372-2420; Fax: (509) 376-4989 
,

$$
\begin{aligned}
& \text { TIIS PAGE INTENTIONATII } \\
& \text { LIITI BLIT }
\end{aligned}
$$


2. Title

TANK 241-AX-102 HEADSPACE GAS AND VAPOR

CHARACTERIZATION RESULTS FOR SAMPLES COLLECTED IN JUNE 1995

5. Key Words

CHARACTERIZATION OBJECTIVES, TANK HEADSPACE,

SAMPLING EVENT, INORGANIC GASES, ORGANIC VAPORS

3. Number

WHC-SD-WM-ER-506

4. Rev No.

0
6. Author

Name: D. R. BRATZEL.

signature

Organization/Charge Code

$75640 / N 4 A B 1$

7. Abstract

Significant changes have been made to all of the original vapor characterization reports. This report documents specific headspace gas and vapor characterization results for all vapor sampling events to date. In addition, changes have been made to the original vapor reports to qualify the data based on quality assurance issues associated with the performing laboratories.

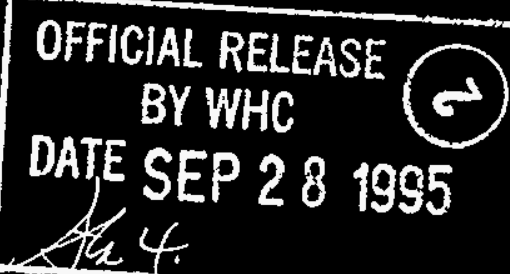




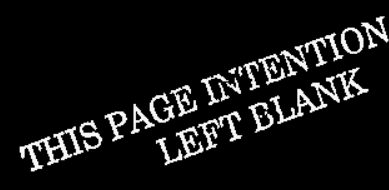


WHC-SD-WM-ER-506

Revision 0

UC-2070

\title{
Tank 241-AX-102 Headspace Gas and Vapor Characterization Results for Samples Collected in June 1995
}

\author{
J. L. Huckaby \\ Pacific Northwest Laboratories \\ D. R. Bratzel \\ Westinghouse Hauford Company
}

Date Published

September 1995

Prepared for the U.S. Department of Energy Office of Environmental Restoration and Waste Management

$\begin{array}{ll}\text { Westinghouse } & \text { P.O Box } 1970 \\ \text { Hanford Company } & \text { Richland, Washington }\end{array}$

Management and Operations Contractor for the

U.S. Department of Energy under Contract DE.AC06-87FL 10930 
.

.

THIS PAGE INTENTIONALWY

LEFT BLANK 


\section{Contents}

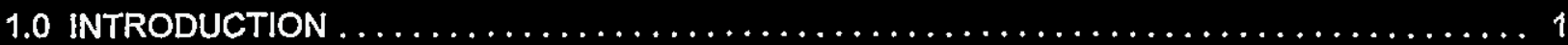

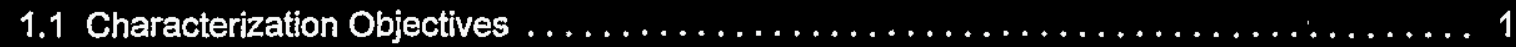

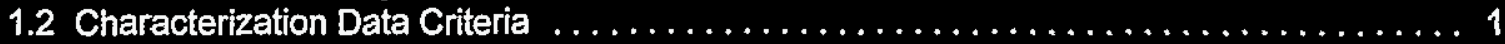

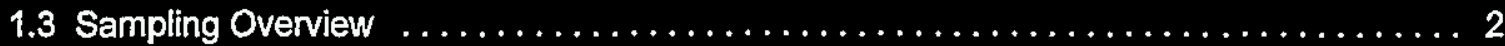

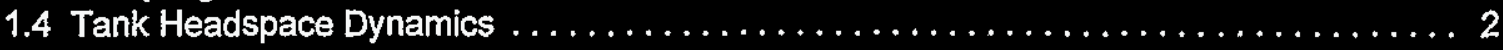

2.0 SAMPLING EVENT $\ldots \ldots \ldots \ldots \ldots \ldots \ldots \ldots \ldots \ldots \ldots \ldots \ldots \ldots \ldots \ldots \ldots \ldots \ldots \ldots$

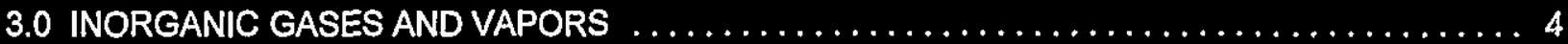

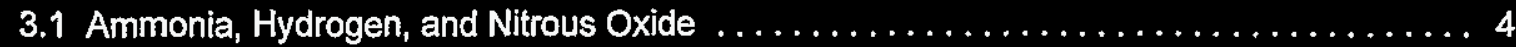

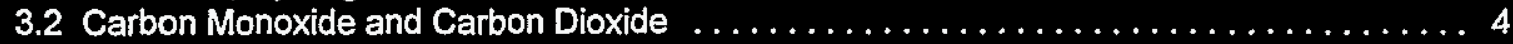

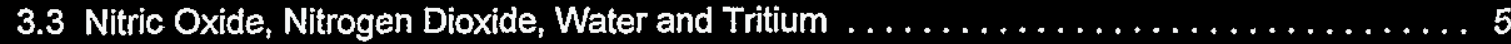

3.4 Discussion of Inorganic Gases and Vapors $\ldots \ldots \ldots \ldots \ldots \ldots \ldots \ldots \ldots \ldots \ldots$

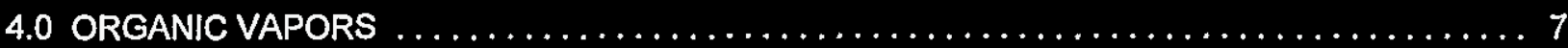

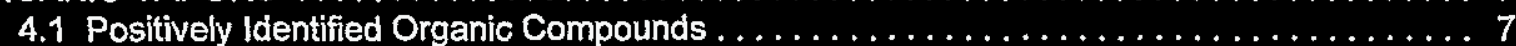

4.2 Tentatively Identified Organic Compounds $\ldots \ldots \ldots \ldots \ldots \ldots \ldots \ldots \ldots \ldots \ldots$

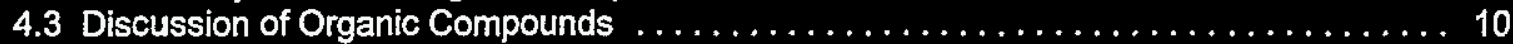

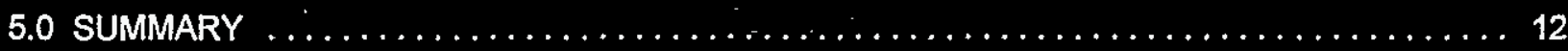

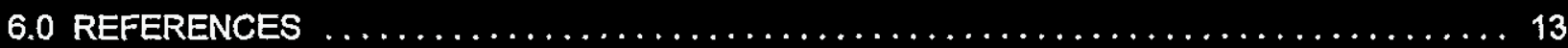

\section{Acronyms and Abbreviations}

$\begin{array}{ll}\text { CES } & \text { consensus exposure standard } \\ \text { EPA } & \text { Environmental Protection Agency } \\ \text { GC } & \text { gas chromatograph } \\ \text { GC/MS } & \text { gas chromatograph/mass spectrometer } \\ \text { LFL } & \text { lower flammability limit } \\ \text { MS } & \text { mass spectrometer } \\ \text { NFPA } & \text { National Fire Protection Association } \\ \text { NPH } & \text { normal paraffinic hydrocarbon } \\ \text { ORNL } & \text { Oak Ridge National Laboratory } \\ \text { PNL } & \text { Pacific Northwest Laboratory } \\ \text { ppmv } & \text { parts per million by volume, } 1 \text { ppmv }=10^{-4} \text { vol\% } \\ \text { TO-14 } & \text { task order 14 } \\ \text { TST } & \text { triple sorbent trap } \\ \text { vol\% } & \text { percent by volume, } 1 \text { vol\% }=10,000 \text { ppmv } \\ \text { VSS } & \text { vapor sampling system } \\ \text { WHC } & \text { Westinghouse Hanford Company } \\ & \\ & \text { Acknowledgements }\end{array}$

The authors wish to thank Chris Simonen for her work verifying data and generating tables, and Shas Mattigod for his help with the construction and reviews of this document. The authors also wish to thank Luther Buckley, Clarence Homi, and Tom Kunthara for their contributions to the final reviews and publication of this document. 
, TIIS PAGE INTENTIONAITI
LITIT BLANTI 
WHC-SD-WM-ER-506 Rev. 0

\title{
Tank 241-AX-102 Headspace Cas and Vapor Characterization Results
}

\author{
for Samples Collected in June 1995
}

\subsection{INTRODUCTION}

\subsection{Characterization Objectives}

Tank AX-102 headspace gas and vapor samples were collected and analyzed to help determine the potential risks of fugitive emissions to tank farm workers. The drivers and objectives of waste tank headspace sampling and analysis are discussed in Program Plan for the Resolution of Tank Vapor /ssues (Osborne and Huckaby 1994). Tank AX-102 was vapor sampled in accordance with Data Quality Objectives for Generic In-Tank Health and Safety Issue Resolution (Osborne et al. 1995).

\subsection{Characterization Data Criteria}

Data Quality Objectives for Generic In-Tank Health and Safety Issue Resolution describes parameters for data collection to ensure appropriate conclusions can be drawn from the data. Tank headspace characterization data were collected to help in the evaluation of 1) headspace flammability, and 2) identification and quantification of compounds of toxicological concern.

Single Shell Tank Interim Operational Safety Requirements (Dougherty 1995) specifies that combustible constituents in tank headspaces be maintained below $25 \%$ of the lower flammability limit (LFL). This essentially agrees with National Fire Protection Association requirements that combustible concentrations be maintained at or below $25 \%$ of the LFL (NFPA 1994). However, current governing operating specifications for Watchlist waste tanks, such as tank AX-102 specify that combustible constituents be maintained at or below $20 \%$ of the LFL (WHC 1995a).

Headspace characterization data is used by Westinghouse Hanford Company (WHC) Tank Waste Remediation Systems Industrial Hygiene as source term data in the industrial hygiene strategy to protect workers from tank fugitive emissions. Because selection of worker protective equipment must be based on industrial hygiene monitoring of the work place and not on source term data (29 CFR 1910.120), tank headspace characterization data can not be used for this purpose. Furthermore, because there are mechanisms by which headspace constituents can be either diluted or concentrated as they are released to the atmosphere, the headspace characterization data should not be considered to be representative of emissions at the point of emission.

These statements notwithstanding, the data quality objectives document specifies that the industrial hygiene group be advised if constituents with toxicological properties exceed $50 \%$ of the appropriate consensus exposure standard (CES) for non-carcinogens, or $10 \%$ of the appropriate CES for carcinogens. A CES is defined as the most stringent of known regulatory or recommended toxicological values for the workplace (Osborne et al. 1995). 


\subsection{Sampling Overview}

Tank headspace characterization data presented here are from a single sampling event. Samples collected are thought to have been representative of tank AX-102 headspace when the tank was sampled (Meacham et al. 1995), and samples analyses were designed to provide a reasonably accurate and complete characterization of the significant headspace constituents. No assessment has been made as to how the tank AX-102 headspace composition changes with time, though studies of tank C-103 suggest that composition changes probably occur very slowly in the passively ventilated tanks (Huckaby and Story 1994)

\subsection{Tank Headspace Dynamics}

Tank AX-102 is the second tank in a 3-tank cascade with tanks AX-101 and AX-103. It is connected to each of these tanks via 7.4-cm (2.9-in.) inside diameter, 7.6-m (25-ft) long underground cascade lines. Since these cascade lines connect the headspaces of these tanks, gases and vapors originating from the wastes in tank AX-101 or tank AX-103 may be transferred to tank AX-102 (unless the cascade lines are obstructed). At this time, however, no headspace characterization data are available for tank AX-101 or AX-103 to assess their potential transfer of gases and vapors to tank AX-102.

The cascade of tanks AX-101, AX-102, and AX-103 is passively ventilated, which means that the tanks are allowed to exhale air, waste gases, and vapors as the barometric pressure falls, and inhale ambient air as the barometric pressure rises. Each of these tanks has its own filtered breather riser. Barometric pressure typically rises and falls on a diurnal cycle, producing an average daily exchange of air equal to about $0.46 \%$ of each tank headspace (Huckaby 1994). Changes in the concentrations of tank headspace constituents due to barometric pressure changes are consequently very slow. 


\subsection{SAMPLING EVENT}

Headspace gas and vapor samples were collected from tank AX-102 using the vapor sampling system (VSS) on June 27, 1995 by WHC Sampling and Mobile Laboratories (WHC 1995b). Sample collection and analysis were performed as directed by Tank 241-AX-102 Tank Characterization Plan (Homi 1995a). The tank headspace temperature was determined to be $24.6^{\circ} \mathrm{C}$. Air from the AX-102 headspace was withdrawn from a single elevation via a 7.9-m long heated sampling probe mounted in riser $9 \mathrm{E}$, and transferred via heated tubing to the VSS sampling manifold. All heated zones of the VSS were maintained at approximately $60^{\circ} \mathrm{C}$. All tank air samples were collected between 10:46 a.m. and 12:59 p.m., with no anomalies noted.

Sampling media were prepared and analyzed by WHC, Oak Ridge National Laboratories (ORNL), and Pacific Northwest Laboratories (PNL). The 52 tank air samples and 2 ambient air control samples collected are listed in Table 2-1 by analytical laboratory. Table 2-1 also lists the 16 trip blanks and 16 field blanks provided by the laboratories.

A general description of vapor sampling and sample analysis methods has been given by Huckaby et al. (1995). The sampling equipment, sample collection sequence, sorbent trap sample air flow rates and flow times, chain of custody information, and a discussion of the sampling event itself are given in WHC 1995b. 


\subsection{INORGANIC GASES AND VAPORS}

Analytical results of sorbent trap and SUMMA ${ }^{T M, 1}$ canister tank air samples for selected inorganic gases and vapors are given in Table 3-1 in parts per million by volume (ppmv) in dry air. The concentration of water vapor reported in Table 3-1 has been adjusted to tank conditions as given in Section 3.3. Inorganic analyte sorbent traps and SUMMA ${ }^{\mathrm{TM}}$ canisters were prepared and analyzed by PNL at PNL quality assurance impact level 2 (Clauss et al. 1995).

Analyses of inorganic analytes in sorbent traps and SUMMA ${ }^{\mathrm{TM}}$ canisters were performed within 24 and 3 days, respectively, after sample collection. This was within the allowed 60-day holding time of the WHC quality assurance project plan (Keller 1994). It should be noted that the 60-day holding time was administratively chosen, and that analytical holding times have not been established by an appropriate study of analyte stabilities in the sampling devices and in the chemical matrix of the tank air samples.

\subsection{Ammonia, Hydrogen, and Nitrous Oxide}

The concentration of ammonia in the headspace of tank AX-102 was determined to be 34 ppmv from 6 sorbent trap samples. Ammonia has been observed in virtually all of the passively ventilated waste tanks sampled to date, at concentrations ranging from about 3 ppmv in tank C-108 (Lucke et al. 1995), to 1040 ppmv in BY-108 (McVeety et al. 1995). Given the LFL of ammonia in air is about $15 \%$ by volume (vol\%), the measured $34 \mathrm{ppmv}$ corresponds to about $0.02 \%$ of the LFL, and does not contribute appreciably to the flammability of the headspace.

The concentration of hydrogen in tank AX-102 was determined to be $<98$ ppmv in each of the 3 SUMMA ${ }^{T M}$ canister samples. Hydrogen in the waste tanks is of concern as a fuel. Given that the LFL for hydrogen in air is about 4 vol\%, the < 98 ppmv hydrogen concentration in tank AX-102 corresponds to $<$ $0.25 \%$ of its LFL. At this level, hydrogen is not a flammability concern in tank AX-102.

The nitrous oxide concentration in tank AX-102 was determined to be 50 ppmv from 3 SUMMA ${ }^{\text {TM }}$ canister samples. Nitrous oxide has been detected in other passively ventilated waste tanks at average concentrations as low as about 12 ppmv in tank TX-105 (Klinger et al. 1995), and as high as 878 ppmv in tank U-103 (Ligotke et al. 1995). Under proper conditions, nitrous oxide can serve as an oxidizer to support combustion. However, Cashdollar et al. (1992) found that nitrous oxide had no significant effect on the flammability of hydrogen and air mixtures for hydrogen concentrations less than $20 \mathrm{vol} \%$, and that "small amounts of nitrous oxide (relative to air) do not appear to have much effect on the flammability". Their results suggest the measured nitrous oxide concentration is much too low to have a significant effect on the flammability of the tank AX-102 headspace.

\subsection{Carbon Monoxide and Carbon Dioxide}

Carbon monoxide in the tank $A X-102$ headspace was reported to be $<12$ ppmv. In ambient air it typically ranges from 0.05 to $0.15 \mathrm{ppmv}$. Because different analytical methods have been used to measure carbon monoxide in the waste tanks sampled to date, the information on carbon monoxide has varied from tank to tank. However, elevated waste tank headspace carbon monoxide concentrations are common, and are

1 SUMMA is a trademark of Molectrics, Inc., Cleveland, Ohio. 
thought to be due to the decomposition of organic waste in the tanks. Carbon monoxide has not been measured at very high levels in any of the waste tanks, the highest level measured to date was [26.7. ppmv] in tank C-1032 (Huckaby and Story 1994).

The carbon dioxide concentration in the tank AX-102 headspace, measured to be $704 \mathrm{ppmv}$, is significantly higher than it is in ambient air. In most tanks that have been sampled the headspace carbon dioxide concentration is lower than it is in ambient air, though several exceptions are known. Carbon dioxide introduced by air exchange with the atmosphere is readily absorbed by caustic supernatant and interstitial liquids of the waste tanks, and converted to carbonate in solution. Carbon dioxide is normally present in the ambient air at a concentration of 350 to 400 ppmv, and is typically between about 10 ppmv to $200 \mathrm{ppmv}$ in the waste tank headspaces. The ambient air samples collected at the start of the tank $A X$ 102 sampling event, for example, contained an average 332 ppmv of carbon dioxide.

The apparent explanation for higher than ambient levels of carbon dioxide in tank AX-102 is that the waste liquids in the tank have relatively high levels of carbonate. Sederberg (1995) examined a similar situation in tank C-101, where the headspace carbon dioxide concentration was measured to be an average $[1,426$ ppmv $]^{3}$. Sederberg found that at the measured pH and waste temperature, the carbonate concentration of waste liquid in tank C-101 was high enough to evolve carbon dioxide (rather than absorb it). Several other tanks have since been observed to have higher than ambient carbon dioxide concentrations, including tanks C-107 and B-103.

\subsection{Nitric Oxide, Nitrogen Dioxide, Water and Tritium}

Nitric oxide and nitrogen dioxide concentrations in the tank AX-102 headspace were determined to be 0.18 and $\leq 0.08 \mathrm{ppmv}$, respectively. These are acid gases that would have very low equilibrium concentrations above the high pH sludge in tank $A X-102$. The measurable presence of nitric oxide is not uncommon in the waste tank headspaces, and may be due to its formation from oxygen and nitrogen in the radiation field of the headspace. These constituents could potentially serve as oxidizers to support combustion, but at the measured concentrations would have a negligible effect on the flammability of the tank AX-102 headspace.

The water vapor concentration of tank AX-102 was determined to be about $11.9 \mathrm{mg} / \mathrm{L}$, at the measured tank headspace temperature of $24.6^{\circ} \mathrm{C}$ and pressure of $996 \mathrm{mbar}$ (747 torr), (WHC 1995b). This corresponds to a water vapor partial pressure of $16.4 \mathrm{mbar}$ ( 12.3 torr), to a dew point of $14.4^{\circ} \mathrm{C}$, and to a relative humidity of $53 \%$.

Silica gel sorbent traps were used to test for tritium. It is assumed that tritium produced by the waste combines with hydroxide ions to form tritium-substituted water. Evaporation of the tritium-substituted water would then result in airborne radioactive contamination. Silica gel sorbent traps adsorb virtually all (normal and tritium-substituted) water vapor from the sampled tank air, and are analyzed at the WHC 222-

\footnotetext{
2 The carbon monoxide measurement in tank C-103 was made by Oregon Graduate Institute of Science and Technology, and placed in brackets to emphasize it should be considered secondary data.

3 This value was determined by Oregon Graduate Institute of Science and Technology, and should be considered a secondary result (Burnum 1995). Huckaby and Bratzel (1995) provide further details and supporting data.
} 
S laboratory. Radiochemical analysis of the silica gel trap indicated the total activity of the headspace to be less than $50 \mathrm{pCi} / \mathrm{L}$ (WHC 1995b).

\subsection{Discussion of Inorganic Gases and Vapors}

Aside from water vapor, the most abundant waste constituents in the tank AX-102 headspace are carbon dioxide, ammonia, and nitrous oxide. Carbon dioxide is apparently desorbed by the waste, where it would exist as some form of carbonate in solution. The carbonate in tank AX-102 was probably introduced as a waste constituent, and is not being generated within the tank. Ammonia and nitrous oxide, by contrast, are thought to be produced by chemical and radiolytic reactions of the waste.

The relative standard deviations of the inorganic gas and vapor results given in the last column in Table 31 are good for the methods used. Relative standard deviations range from about $0.9 \%$ for carbon dioxide, to about $9 \%$ for ammonia. Because the precision reported depends both on sampling parameters (e.g., sample flow rate and flow time for sorbent traps) and analytical parameters (e.g., sample preparation, dilutions, etc.), small relative standard deviations suggest proper control was maintained both in the field and in the laboratories. 


\subsection{ORGANIC VAPORS}

Organic vapors in the tank AX-102 headspace were sampled using SUMMA ${ }^{\mathrm{TM}}$ canisters, which were analyzed by PNL, and triple sorbent traps (TSTs), which were analyzed by both PNL and ORNL. To the extent possible, identical sets of TSTs were collected for PNL and ORNL, though each laboratory prepared their own samples. Both PNL and ORNL used gas chromatographs (GCs) equipped with mass spectrometer (MS) detectors to separate, identify, and quantitate the analytes. Descriptions of sample device cleaning, sample preparations, and analyses are given by Jenkins et al. (1995) and Clauss et al. (1995).

PNL SUMMA ${ }^{\mathrm{TM}}$ results should be considered the primary organic vapor data for tank AX-102. These results were produced at PNL quality assurance impact level 2. PNL preparation and analyses of TST samples were performed at PNL quality assurance impact level 3. PNL analyses of TSTs and SUMMA ${ }^{\text {TM }}$ canisters for organic vapors were completed 30 and 8 days, respectively, after sample collection. These satistied the administratively chosen 60-day holding time (Keller 1994). PNL has not conducted holding time studies to determine the stability of organic compounds in either SUMMATM canisters or TSTs in the chemical matrix of the tank air samples.

ORNL analyses of TST samples from this and other waste tanks generally agree with, support, and augment the SUMMATM sample results. However, because certain WHC quality assurance requirements were not satisfied by ORNL, the quality assurance assessment of ORNL by Hendricksori (1995) should be reviewed before results unique to the TST samples are used for decision making.

All TSTs prepared by ORNL had 3 surrogate compounds added to evaluate sample matrix effects, potential handing, storage, and shipment problems, and analytical instrumentation performance. ORNL evaluated the surrogate recoveries using a statistical approach similar to that prescribed by $S W 846$ Method 8260A Volatile Organic Compounds by Gas Chromatography/Mass Spectrometry (GCMS) Capillary Column Technique (EPA 1992). Using this approach, ORNL reported that all surrogates had standard deviation values within the $95 \%$ confidence interval for variance, indicating that no bias was introduced in the measurement of analyte quantities (Jenkins et al. 1995).

PNL used the same number and type of surrogate spikes as were used by ORNL. Surrogate recoveries by PNL were comparable to those of ORNL, but the ORNL statistical criteria are not directiy applicable. A statistical treatment of PNL surrogate recoveries, similar to that done by ORNL, has not been performed in part because of insufficient data. Surrogates have been used by PNL only as indicators of gross sample matrix, handling, storage, and shipment problems, and no such problems were indicated in the tank AX102 TST samples.

\subsection{Positively Identified Organic Compounds}

Positive identification of organic analytes using the methods employed by PNL and ORNL involves matching the GC retention times and MS data from a sample with that obtained from the analysis of standards. The concentration of an analyte in the sample is said to be quantitatively measured if the response of the GC/MS has been established at several known concentrations of that analyte (i.e., the GC/MS has been calibrated for that analyte), and the MS response to the analyte in the sample is between the lowest and highest responses to the known concentrations (i.e., the analyte is within the calibration range). 


\section{WHC-SD-WM-ER-506 Rev. 0}

ORNL and PNL were assigned different lists of organic compounds, or target analytes, to positively identify and measure quantitatively. The ORNL target analyte list was derived from a review of the tank $C_{-}$ 103 headspace constituents by a panel of toxicology experts (Mahlum et al. 1994). The PNL target analyte list included 39 compounds from the Environmental Protection Agency (EPA) task order 14 (TO14) method, which are primarily halocarbons and common industrial solvents (EPA 1988), plus 14 analytes selected mainly from the toxicology panel's review of tank C-103. For cost efficiencies, PNL analyzed for the same set of target analytes in both SUMMA ${ }^{\text {TM }}$ and TST samples. This was also done to obtain maximum comparison of the methods.

Table 4-1 lists the organic compounds positively identified and quantitated in SUMMA ${ }^{T M}$ samples. Results given in Table 4-1 were obtained using the EPA TO-14 methodology, except for analysis of methane, which was analyzed with the inorganic gases (Clauss et al. 1995). Only 9 organic analytes were positively identified in SUMMA ${ }^{\text {TM }}$ samples (1 from the TO-14 list of 39 analytes, and 8 from the list of additional analytes). Others were determined to be present below the 0.005 ppmv detection limit of the analyses. Averages reported are from analyses of 3 SUMMA ${ }^{T M}$ canister samples. The precision of the SUMMA ${ }^{T M}$ sample measurements was good, as indicated by the very small relative standard deviations given in the last column of Table 4-1.

The positively identified and quantitated analytes in PNL TST samples, with their average concentrations, are listed in Table 4-2. These are also given with the analogous PNL SUMMATM canister results in Table 4.3 for comparison. In addition to the 9 analytes positively identified in SUMMA ${ }^{\mathrm{TM}}$ canisters, 2 other analytes (dichloromethane and toluene) were also detected in the TST samples. These 2 additional analytes were determined to be virtually at the detection limit of the analyses. In general, the agreement between these 2 methods is quite good, as indicated by the calculated relative percent differences in the last column of Table 4-3. As with the SUMMA ${ }^{\text {TM }}$ sample analyses, target analytes not reported in Table 42 were deemed to be below the 0.005 ppmv detection limit. The largest discrepancy between the 2 methods is for the measurement of 1-propanol, which was detected in SUMMA ${ }^{\text {TM }}$ samples at an average $0.026 \mathrm{ppmv}$, and in TST samples at $0.053 \mathrm{ppmv}$.

Jenkins et al. (1995) positively identified 26 of 27 target analytes in TST samples. Dichloromethane was the only TST target anaiyte not detected. Despite calibration of the instrument over about a 20-fold concentration range, only 11 of the target analytes were measured to be within the calibration range in all 3 TST samples. Tables 4-4 through 4-6 give the reported 3-sample average concentrations for 24 positively identified compounds. Quantitated compounds are given in Table 4-4, compounds for which the measurement in 1 or more samples was outside the instrument calibration range are given in Table 4-5, and compounds for which the ORNL practical holding time was exceeded are given in Table 4-6. Tables 4-4, 4-5, and 4-6 are mutually exclusive, so no compound appears in more than 1 of these tables. Note that 1 compound in Table 4-6, butanal, was quantitated in all 3 samples, but placed in Table 4-6 because it exceeded its practical holding time. Data in Tables 4-5 and 4-6 may not be accurate to within $\pm 30 \%$ as specified by Burnum (1995).

The ORNL practical holding time is defined as the holding time for which there is a $15 \%$ risk that the concentration of an analyte in the sample will be below its initial concentration (Jenkins et al. 1995). The 3 compounds listed in Table 4-6 (butanal, 1-butanol, and 2-pentanone) had exceeded their practical holding times when the samples were analyzed 43 days after being collected. It should be noted that the practical holding times of some compounds are very short; butanal, for example, has a practical holding time of only 1 day.

Tributyl phosphate and dibutyl butylphosphonate were both positively identified by ORNL. in one of the TST samples, but these results are suspect because of an apparent sampling manifold contamination 
WHC-SD-WM-ER-506 Rev. 0

problem. Huckaby and Bratzel (1995b) briefly describe the evidence that tributyl phosphate and dibutyl butylphosphate were contaminants of several sampling events. Furthermore, because calibration of the instrumentation for these compounds requires special procedures and these compounds have other known sampling problems, quantitation was not attempted.

Both PNL and ORNL report target analyte concentrations in ppmv of analyte in dry air. To correct for the measured water vapor content of tank AX-102 and obtain concentration in ppmv of analyte in moist tank air, multiply by 0.969 .

Collection of TST samples was conducted in a manner to minimize inter-laboratory differences. Specifically, identical sample volumes were drawn through like sets of TSTs (though the design of the TSTs used by the 2 laboratories is slightly different), and they were collected simultaneously from alternate locations of the sorbent trap sampling station of the VSS. Table 4-7 lists the 10 target analytes that were common to both ORNL and PNL analyses, with their measured concentrations in PNL SUMMA ${ }^{T M}$ samples, PNL TST samples, and ORNL TST samples. Comparison of the data given in Table 4-7 suggests the 3 sampling and analysis methodologies are in very good agreement. No consistent laboratory or sample device bias is indicated by the data given in Table 4-7.

Four positively identified analytes in tank AX-102 were measured to be above $0.1 \mathrm{ppmv:}$ 1-butanol, propanone (acetone), ethanenitrile (acetonitrile), and trichlorofluoromethane. At the reported concentrations, these headspace constituents do not individually or collectively represent a flammability hazard.

\subsection{Tentatively Identified Organic Compounds}

In addition to the target analytes, the ORNL and PNL analytical procedures allow the tentative identification of other organic compounds. Tentative identification of analytes was performed by comparing the MS molecular fragmentation patterns with a library of known MS fragmentation patterns.

This method allows an organic analyte to be identified (with reasonable certainty) as an alkane, a ketone, an aldehyde, etc., and may also determine its molecular weight. The method usually does not, however, allow the unambiguous identification of structural isomers, and this ambiguity increases with analyte molecular weight. Using this method, many analytes can be tentatively identified with reasonable confidence without having to inject standards of each into the GC/MS to determine their GC retention times or specific MS patterns.

By the nature of the sampling devices, virtually all organic vapors present in the tank headspace are collected by both TST and SUMMA ${ }^{\text {TM }}$ samples. Analyses of the samples are designed to recover, separate, identify, and quantify the organic vapors in the samples. TSTs are not good for collecting highly volatile compounds (i.e., molecules more volatile than propane), but are quite good for most others. In contrast, the recovery of very low volatility compounds (e.g., molecules with more than about 15 carbon atoms) and some polar compounds with moderate volatility (e.g., butanal) from SUMMA ${ }^{\text {TM }}$ samples has been problematic.

The lists of tentatively identified compounds recovered from PNL SUMMA ${ }^{T M}$ and PNL TST samples with their estimated concentrations, are given in Tables 4-8 and 4-9, respectively. Compounds are listed in these tables in the order in which they eluted chromatographically, and only non-zero results are included in the reported averages. Estimated concentrations are in $\mathrm{mg} / \mathrm{m}^{3}$, based on dry air at $0^{\circ} \mathrm{C}$ and 1.01 bar. 
The list of tentatively identified compounds detected in ORNL TST samples, and their estimated concentrations, is given in Table 4-10. Compounds in Table 4-10 are also listed in the order in which the eluted chromatographically. The averages reported by ORNL in Table 4-10 are all 3-sample averages, and if an analyte was not detected in a sample, its concentration in that sample was considered to be zero for averaging purposes. Because the ORNL list of tentatively identified compounds is long and locating any given compound may be difficult, it has been sorted alphanumerically by compound name in Table 411, and by estimated concentration in Table 4-12. Numbers in the first column of Tables 4-11 and 4-12 (Cmpd \#) refer to the location of the compound in Table 4-10. Estimated concentrations are in $\mathrm{mg} / \mathrm{m}^{3}$, based on dry air at $0^{\circ} \mathrm{C}$ and 1.01 bar.

The ORNL and PNL methods used to tentatively identify and estimate concentrations are described by Jenkins et al. (1995) and Clauss et al. (1995), respectively, and should be reviewed before this data is used for decision making. Concentrations given in Tables 4-8 through and 4-12 should be considered estimates.

\subsection{Discussion of Organic Compounds}

Some of the organic compounds identified in the June 1995 tank AX-102 headspace samples are apparently from residual organic solvents still present in the tank waste. In particular, the semivolatile straight-chain alkanes were used as diluents of tributyl phosphate in various plutonium extraction processes. These alkanes (i.e., n-undecane, n-dodecane, n-tridecane, n-tetradecane, and npentadecane) are often referred to in Hanford site literature as the normal paraffinic hydrocarbons (NPHs). Tributyl phosphate itself was detected by ORNL in TST samples, as well as dibutyl butylphosphonate, a common contaminant present from the manufacture of tributyl phosphate, but these may also have been present in the TST samples because of a sampling manifold contamination problem. It is also likely that the tentatively identified semivolatile branched alkanes were also introduced with the NPHs as waste.

The concentrations of the NPHs in the tank AX-102 headspace are too high and the solubilities of the NPHs in aqueous wastes are too small to assume that they are dissolved in the aqueous waste of tank AX-102. An organic liquid phase of some sort probably exists, though whether it resides as a small puddle or is lightly smeared over different parts of the tank and waste can not be determined from vapor samples. The headspace concentrations of these semivolatile constituents depend on the amount of organic-phase surface area, the temperature of the organic-phase, and the ventilation rate of the tank.

Though the NPHs are not present at high concentrations in the headspace of tank AX-102, they are thought to be the precursors of most of the other organic compounds identified in tank AX-102. Condensed phase chemical and radiolytic reactions degrade the NPHs into shorter carbon chain molecules, such as the volatile nitriles, aldehydes, alcohols, and alkenes. The abundance of these in the headspace probably depends on their generation rates and the tank ventilation rate, because they are relatively volatile, and probably do not remain in the organic liquid phase in significant concentrations. Other degradation products of the NPHs may include non-volatile acids (which would be converted to salts on contact with the aqueous waste), and high-molecular weight compounds with very low volatilities.

Tetrachloroethene, a chlorinated solvent, was positively identified in the tank AX-102 samples. This common cleaning solvent may have been added to the tank in small quantities when it became radiologically contaminated. The other positively identified halogenated compound, trichlorofluoromethane, is a freon (and not really a solvent), with a boiling point of about $23^{\circ} \mathrm{C}$. The source of this is not known, but it is frequently detected in the waste tank headspaces. One plausible explanation for its presence is that it was the gas component of urethane foam that was used to seal 
WHC-SD-WM-ER-506 Rev. 0

concrete pit covers on the tanks. Whether this type of foam was used on tank AX-102 has not been determined.

The total organic vapor concentration in PNL TST and SUMMA ${ }^{\mathrm{TM}}$ canister samples was determined (by GC/MS) to be $7.38 \mathrm{mg} / \mathrm{m}^{3}$ and $9.90 \mathrm{mg} / \mathrm{m}^{3}$, respectively (Clauss et al. 1995). These estimates differ primarily because of the relatively high concentration of methanol, $4.0 \mathrm{mg} / \mathrm{m}^{3}$, found in SUMMA ${ }^{\mathrm{TM}}$ canister samples. Methanol in PNL TSTs was estimated to be only $0.42 \mathrm{mg} / \mathrm{m}^{3}$, and a plausible explanation is that methanol is not well retained (trapped) by TSTs (the ORNL methanol estimate is also low, $0.79 \mathrm{mg} / \mathrm{m}^{3}$ ). A similar summation of quantitative, semiquantitative, and estimated organic vapor concentrations reported by ORNL from TST analyses (also by GC/MS) gave an estimated $7.6 \mathrm{mg} / \mathrm{m}^{3}$ of organic vapors (Jenkins et al. 1995). The PNL TST and ORNL TST estimates of total organic vapor concentration are in excellent agreement.

In general, the organic vapors in tank AX-102 are similar to those observed in other passively ventilated waste tanks at the Hanford site. The estimated total organic vapor concentration, ranging from 7.38 to $9.90 \mathrm{mg} / \mathrm{m}^{3}$, is typical for the passively ventilated tanks that have been sampled. 


\subsection{SUMMARY}

The tank AX-102 headspace was sampled in June 1995 for gases and vapors to address flammability and industrial hygiene concerns. Results of sample collection and analysis have been reported. It was determined that no headspace constituents exceeded the flammability or industrial hygiene notification limits specified in the current Vapor Sampling and Analysis Plan (Homi 1995b). 


\subsection{REFERENCES}

29 CFR 1910.120, 1993, "Hazardous Waste Operations and Emergency Response", Code of Federal Regulations.

Burnum, S. T., 1995, Qualification of Reported WHC Vapor Program Data, (letter 95-CHD-065 to president, Westinghouse Hanford Company, August 18), Department of Energy, Richland Operations Office, Richland, Washington.

Cashdollar, K. L..,M. Hertzberg, I. A. Zlochower, C. E. Lucci, G. M. Greeñ, and R. A. Thomas, 1992, Laboratory Flammability Studies of Mixtures of Hydrogen, Nitrous Oxide, and Air, WHC-SD-WMES-219 Rev. 0, Westinghouse Hanford Company, Richland, Washington.

Clauss, T. W., M. W. Ligotke, K. H. Pool, B. L. Thomas, B. D. MoVeety, K. B. Olsen, J. S. Fruchter, and S. C. Goheen, 1995, Vapor Space Characterization of Waste Tank 241-AX-102: Results from Samples Collected on 6/27/95, PNL-10809 UC-606, Pacific Northwest Laboratory, Richland, Washington.

Dougherty, L. F., 1995, Single Shell Tank Interim Operational Safety Requirements, WHC-SD-WM-OSR005 Rev. 0, Westinghouse Hanford Company, Richland, Washington.

EPA 1988, Compendium of Methods for the Determination of Toxic Organic Compounds in Ambient Air, PB90-127374, U.S. Environmental Protection Agency, Washington, D.C.

EPA 1992, Test Methods for Evaluating Solid Waste, SW-846 Rev. 1, U.S. Environmental Protection Agency, Washington, D.C.

Hendrickson, R. W., 1995, Tank Vapor_Characterization Oak Ridge National Laboratories Quality Assurance Assessment, TWRSQA-95-0012, Westinghouse Hanford Company, Richland, Washington.

Homi, C. S., 1995a, Tank 241-AX-102 Tank Characterization Plan, WHC-SD-WM-TP-227 Rev. 1, Westinghouse Hanford Company, Richland, Washington.

Homi, C. S., 1995b, Vapor Sampling and Analysis Plan, WHC-SD-WM-TP-335 Rev. 0G, Westinghouse Hanford Company, Richland, Washington.

Huckaby, J. L., 1994, Tank 241-C-103 Headspace Flammability, WHC-EP-0734 Rev. 1, Westinghouse Hanford Company, Richland, Washington.

Huckaby, J. L. H. Babad, and D. R. Bratzel, 1995, Headspace Gas and Vapor Characterization Summary for the 43 Vapor Program Suspect Tanks, WHC-SD-WM-ER-514 Rev. 0, Westinghouse Hanford Company, Richland, Washington.

Huckaby, J. L., 1995a, Tank 241-C-101 Headspace Gas and Vapor Characterization Results for Samples Collected in September 1994, WHC-SD-WM-ER-458, Rev. 1, Westinghouse Hanford Company, Richland, Washington. 


\section{WHC-SD-WM-ER-506 Rev. 0}

Huckaby, J. L., 1995b, Tank 241-U-204 Headspace Gas and Vapor Characterization Results for Samples Collected in August 1995, WHC-SD-WM-ER-513 Rev. 0, Westinghouse Hanford Company, Richland, Washington.

Huckaby, J. L., and M. S. Story, 1994, Vapor Characterization of Tank 241-C-103, WHC-EP-0780 Rev. 0, Westinghouse Hanford Company, Richland, Washington.

Jenkins, R. A, A. B. Dindal, C. Y. Ma, M. A. Palausky, J. T. Skeen, and C. K. Bayne, 1995, Analysiș of Tank 241-AX-102 Headspace Components, ORNL-CASD-FR-241AX102.95 Rev. 0, Oak Ridge National Laboratory, Oak Ridge, Tennessee.

Keller, K. K., 1994, Quality Assurance Project Plan for Tank Vapor Characterization, WHC-SD-WMQAPP-013 Rev. 2, Westinghouse Hanford Company, Richland, Washington.

Klinger, G. S., T. W. Clauss, M. W. Ligotke, K. H. Pool, R. B. Lucke, B. D. MoVeety, O. P. Bredt, J. S. Young, M. McCulloch, J. S. Fruchter, and S. C. Goheen, 1995, Vapor Space Characterization of Waste Tank 241-TX-105: Results from Samples Collected Through the Vapor Sampling System on 12/20/94, PNL-10594 UC-606, Pacific Northwest Laboratory, Richland, Washington.

Ligotke, M. W., K. H. Pool, T. W. Clauss, B. D. MoVeety, G. S. Klinger, K. B. Olsen, O. P. Bredt, J. S. Fruchter, and S. C. Goheen, 1995, Vapor Space Characterization of Waste Tank 241-U-103: Results from Samples Collected on 2/15/95, PNL-10813 UC-606, Pacific Northwest Laboratory, Richland, Washington.

Lucke, R. B., M. W. Ligotke, K. H. Pool, T. W. Clauss, A. K. Sharma, B. D. McVeety, M. McCulloch, J. S. Fruchter, and S. C. Goheen, 1995, Vapor Space Characterization of Waste Tank 241-C-108: Results from Samples Collected Through the Vapor Sampling System on 8/5/94, PNL-10351 UC606, Pacific Northwest Laboratory, Richland, Washington.

Mahlum, D. D., J. Y. Young, and R. E. Weller, 1994, Toxicologic Evaluation of Analytes from Tank 231-C103, PNL-10189, Pacific Northwest Laboratory, Richland, Washington.

MoVeety, B. D., T. W. Clauss, M. W. Ligotke, K. H. Pool, R. B. Lucke, G. S. Klinger, J. S. Young, M. McCulloch, J. S. Fruchter, and S. C. Goheen, 1995, Vapor Space Characterization of Waste Tank 241-BY-108: Results from Samples Collected on 10/27/94, PNL-10495 UC-606, Pacific Northwest Laboratory, Richland, Washington.

Meacham, J. E., H. Babad, R. J. Cash, G. T. Dukelow, S. J. Eberiein, D. W. Hamilton, G. D. Johnson, J. W. Osborne, M. A. Payne, D. J. Sherwood, D. A. Turner, and J. L. Huckaby, 1995, Approach for Tank Safety Characterization of Hanford Site Waste, WHC-EP-0843 Rev. 0 UC-2070, Westinghouse Hanford Company, Richland, Washington.

NFPA 1992, Standard on Explosion Prevention Systems, NFPA 69, National Fire Protection Association, Quincy, Massachusetts.

Osborne, J. W. and J. L. Huckaby, 1994, Program Plan for the Resolution of Tank Vapor Issues, WHCEP-0562 Rev. 1, Westinghouse Hanford Company, Richland, Washington. 


\section{WHC-SD-WM-ER-506 Rev. 0}

Osborne, J. W., J. L. Huckaby, T. P. Rudolph, E. R. Hewitt, D. D. Mahlum, J. Y. Young, and C. M. Anderson, 1995, Data Quality Objectives for Generic In-Tank Health and Safety Issue Resolution, WHC-SD-WM-DQO-002 Rev. 1, Westinghouse Hanford Company, Richland, Washington.

WHC 1995a, Operating Specifications for Watchlist Tanks, OSD-T-151-00030, Rev. B-9, Westinghouse Hanford Company, Richland, Washington.

WHC 1995b, Vapor and Gas Sampling of Single-Shell Tank 241-AX-102 Using the Vapor Sampling System, WHC-SD-WM-RPT-171, Westinghouse Hanford Company, Richland, Washington. 

WHC-SD-WM-ER-506 Rev. 0

Table 2-1

Tank AX-102 Gas and Vapor Sample Type and Number

\begin{tabular}{|c|c|c|c|c|}
\hline Laboratory & Sampling Device & $\begin{array}{c}\text { Nominal Sample } \\
\text { Volume (L) }\end{array}$ & Target Analytes & Number of Samples \\
\hline $\begin{array}{l}\text { Oak Ridge National } \\
\text { Laboratories }\end{array}$ & Triple Sorbent Trap & $\begin{array}{l}0.2 \\
1.0 \\
4.0\end{array}$ & $\begin{array}{l}\text { Organic vapors } \\
\text { Organic vapors } \\
\text { Organic vapors }\end{array}$ & $\begin{array}{l}4 \text { tank air samples } \\
4 \text { tank air samples } \\
4 \text { tank air samples } \\
+2 \text { trip blanks } \\
+2 \text { field blanks } \\
\end{array}$ \\
\hline \multirow[t]{5}{*}{$\begin{array}{l}\text { Pacific Northwest } \\
\text { Laboratories }\end{array}$} & $\begin{array}{l}\text { Acidified Carbon Sorbent } \\
\text { Trap }\end{array}$ & 3.0 & Ammonia & $\begin{array}{l}6 \text { tank air samples } \\
+3 \text { trip blanks } \\
+3 \text { field blanks }\end{array}$ \\
\hline & $\begin{array}{l}\text { Triethanolamine Sorbent } \\
\text { Trap }\end{array}$ & 3.0 & Nitrogen Dioxide & $\begin{array}{l}6 \text { tank air samples } \\
+3 \text { trip blanks } \\
+3 \text { field blanks }\end{array}$ \\
\hline & $\begin{array}{l}\text { Oxidation Bed }+ \\
\text { Triethanolamine Sorbent } \\
\text { Trap }\end{array}$ & 3.0 & Nitric Oxide & $\begin{array}{l}6 \text { tank air samples } \\
+3 \text { trip blanks } \\
+3 \text { field blanks }\end{array}$ \\
\hline & Silica Gel Sorbent Trap & 3.0 & Water vapor & $\begin{array}{l}6 \text { tank air samples } \\
+3 \text { trip blanks } \\
+3 \text { field blanks }\end{array}$ \\
\hline & SUMMA ${ }^{\mathrm{TM}}$ canister & 6.0 & $\begin{array}{l}\text { Carbon Dioxide, } \\
\text { Carbon Monoxide, } \\
\text { Hydrogen, Methane, } \\
\text { Nitrous Oxide, Organic } \\
\text { vapors }\end{array}$ & $\begin{array}{l}3 \text { tank air samples } \\
+2 \text { ambient air samples }\end{array}$ \\
\hline
\end{tabular}


WHC-SD-WM-ER-506 Rev. 0

\begin{tabular}{|c|c|c|c|c|}
\hline Laboratory & Sampling Device & $\begin{array}{c}\text { Nominal Sample } \\
\text { Volume (L) }\end{array}$ & Target Analytes & Number of Samples \\
\hline & Triple Sorbent Trap & $\begin{array}{l}0.2 \\
1.0 \\
4.0\end{array}$ & $\begin{array}{l}\text { Organic vapors } \\
\text { Organic vapors } \\
\text { Organic vapors }\end{array}$ & $\begin{array}{l}4 \text { tank air samples } \\
4 \text { tank air samples } \\
4 \text { tank air samples } \\
+2 \text { trip blanks } \\
+2 \text { field blanks } \\
\end{array}$ \\
\hline WHC 222-S Laboratory & Silica Gel Sorbent Trap & 1.0 & $\begin{array}{l}\text { Tritium-Substituted Water } \\
\text { Vapor }\end{array}$ & 1 tank air sample \\
\hline
\end{tabular}




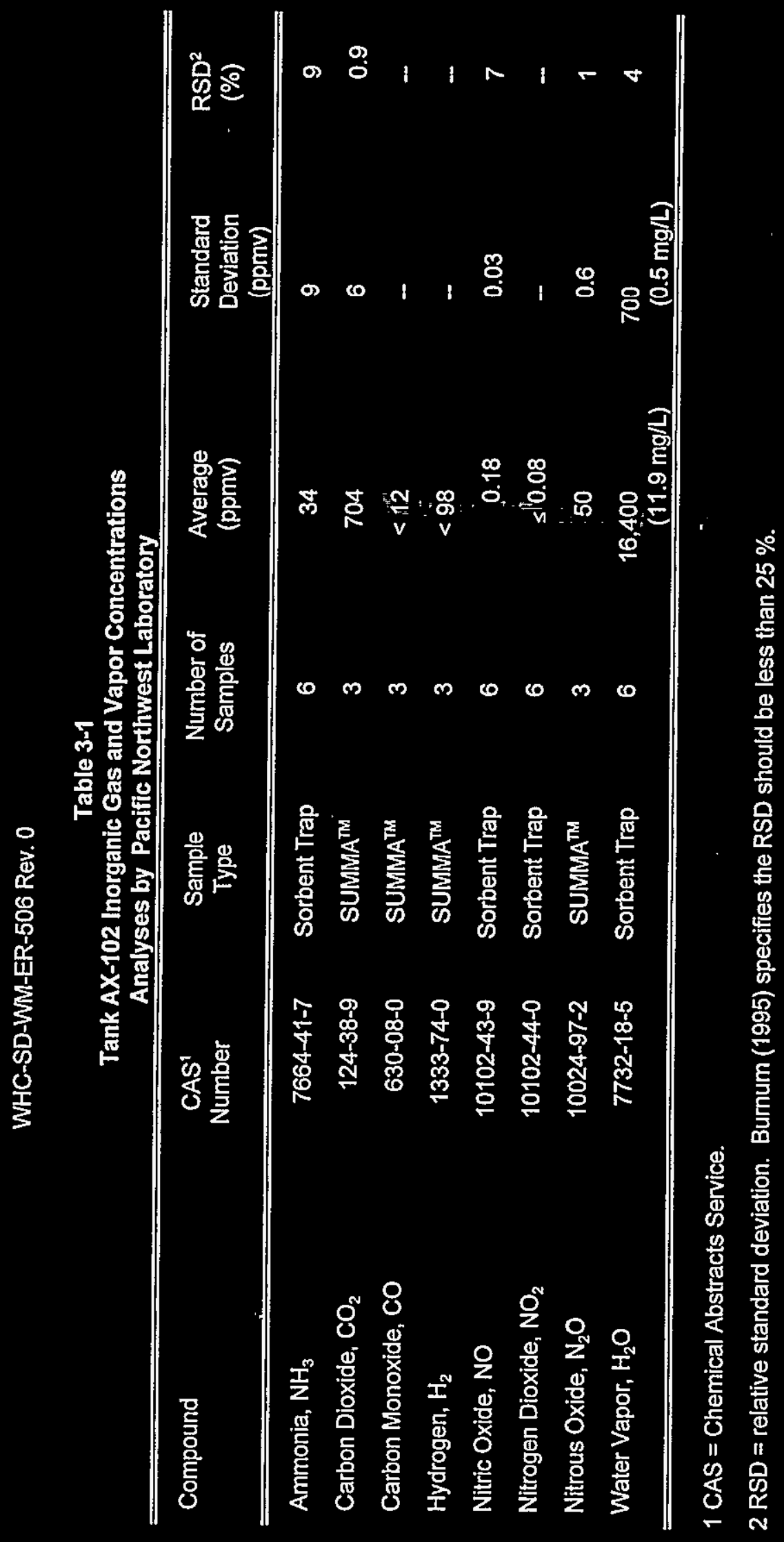


THIS PAGE INTENTIONALIY

LEFT BLANK 
Table 4-1

Tank AX-102 Quantitatively Measured Compounds in SUMMA ${ }^{\text {TM }}$ Samples -Analyses by Pacific Northwest Laboratory

\begin{tabular}{clcccc}
\hline $\begin{array}{c}\text { Cmpd } \\
\#\end{array}$ & Compound & $\begin{array}{c}\text { CAS }^{1} \\
\text { Number }\end{array}$ & $\begin{array}{c}\text { Average } \\
\text { (ppmv) }\end{array}$ & $\begin{array}{c}\text { Standard } \\
\text { Deviation } \\
\text { (ppmv) }\end{array}$ & $\begin{array}{c}\mathrm{RSD}^{3} \\
(\%)\end{array}$ \\
\hline 1 & Ethanenitrile (acetonitrile) & $75-05-8$ & 0.26 & 0.03 & 12 \\
2 & Propanone (acetone) & $67-64-1$ & 0.22 & 0.02 & 9 \\
3 & Trichlorofluoromethane & $75-69-4$ & 0.40 & 0.04 & 10 \\
4 & Propanenitrile & $107-12-0$ & 0.045 & 0.004 & 9 \\
5 & 1-Propanol & $71-23-8$ & 0.026 & 0.002 & 8 \\
6 & 2-Butanone & $78-93-3$ & 0.043 & 0.004 & 9 \\
7 & n-Butanenitrile & $109-74-0$ & 0.088 & 0.007 & 8 \\
8 & n-Heptane & $142-82-5$ & 0.011 & 0.001 & 9 \\
9 & Tetrachloroethylene & $127-18-4$ & 0.024 & 0.001 & 4 \\
10 & Methane & $74-82-8$ & $<12$ & - & - \\
\hline \hline
\end{tabular}

$1 \mathrm{CAS}=$ Chemical Abstract Service.

2 Average of 3 samples.

3 RSD = relative standard deviation. Burnum (1995) specifies the RSD should be less than $25 \%$. 
WHC-SD-WM-ER-506 Rev. 0

Table 4-2

Tank AX-102 Quantitatively Measured Compounds in TST Samples -Analyses by Pacific Northwest Laboratory

\begin{tabular}{clcccc}
$\begin{array}{c}\text { Compd } \\
\#\end{array}$ & Compound & $\begin{array}{c}\text { CAS }^{1} \\
\text { Number }\end{array}$ & $\begin{array}{c}\text { Average } \\
\text { (ppmv) }\end{array}$ & $\begin{array}{c}\text { Standard } \\
\text { Deviation } \\
\text { (ppmv) }\end{array}$ & $\begin{array}{c}\text { RSD }^{3} \\
(\%)\end{array}$ \\
\hline 1 & Ethanenitrile (acetonitrile) & $75-05-8$ & 0.16 & 0.003 & 2 \\
2 & Propanone (acetone) & $67-64-1$ & 0.17 & 0.01 & 7 \\
3 & Trichlorofluoromethane & $-75-69-4$ & 0.25 & 0.001 & 1 \\
4 & Dichloromethane (methylene chloride) & $75-09-2$ & 0.0063 & 0.0007 & 12 \\
5 & Propanenitrile & $107-12-0$ & 0.075 & 0.008 & 11 \\
6 & 1-Propanol & $71-23-8$ & 0.053 & 0.005 & 9 \\
7 & 2-Butanone & $78-93-3$ & 0.051 & 0.001 & 1 \\
8 & n-Butanenitrile & $109-74-0$ & 0.085 & 0.001 & 1 \\
9 & n-Heptane & $142-82-5$ & 0.014 & 0.0003 & 2 \\
10 & Toluene & $108-88-3$ & 0.0055 & 0.0004 & 7 \\
11 & Tetrachloroethylene & $127-18-4$ & 0.025 & 0.001 & 2 \\
\hline \hline
\end{tabular}

$1 \mathrm{CAS}=$ Chemical Abstract Service.

2 Average of 3 samples.

3 RSD = relative standard deviation. Burnum (1995) specifies the RSD should be less than $25 \%$. 
Table 4-3

Tank AX-102 Comparison of Organic Compounds in TST and SUMMA ${ }^{\text {TM }}$ Samples -Analyses by Pacific Northwest Laboratory

\begin{tabular}{lcccc}
\hline Compound & $\begin{array}{c}\text { CAS } \\
\text { Number }\end{array}$ & $\begin{array}{c}\text { TST } \\
\text { Average } \\
\text { (ppmv) }\end{array}$ & $\begin{array}{c}\text { SUMMA }^{\text {TM }} \\
\text { Average }^{3} \\
\text { (ppmv) }\end{array}$ & $\begin{array}{c}\text { RPD }^{4} \\
(\%)\end{array}$ \\
\hline \hline Ethanenitrile (acetonitrile) & $75-05-8$ & 0.16 & 0.26 & -48 \\
Propanone (acetone) & $67-64-1$ & 0.17 & 0.22 & -26 \\
Trichlorofluoromethane & $75-69-4$ & 0.25 & 0.40 & -46 \\
Dichloromethane (methylene chloride) & $75-09-2$ & 0.0063 & $<0.005$ & - \\
Propanenitrile & $107-12-0$ & 0.075 & 0.045 & 50 \\
1-Propanol & $71-23-8$ & 0.053 & 0.026 & 68 \\
2-Butanone & $78-93-3$ & 0.051 & 0.043 & 17 \\
n-Butanenitrile & $109-74-0$ & 0.085 & 0.088 & -3 \\
n-Heptane & $142-82-5$ & 0.014 & 0.011 & 24 \\
Toluene & $108-88-3$ & 0.0055 & $<0.005$ & -- \\
Tetrachloroethylene & $127-18-4$ & 0.025 & 0.024 & 4 \\
\hline \hline
\end{tabular}

$1 \mathrm{CAS}=$ Chemical Abstract Service.

2 Average of 3 TST sample analyses by PNL.

3 Average of 3 SUMMA ${ }^{\text {TM }}$ sample analyses by PNL.

$4 \mathrm{RPD}=$ relative percent difference (i.e., the difference divided by the mean of the 2 values). 
WHC-SD-WM-ER-506 Rev. 0

Table 4-4

Tank AX-102 Quantitatively Measured Organic Analytes in TST Samples-Analyses by Oak Ridge National Laboratory ${ }^{1}$

\begin{tabular}{clcccc}
\hline $\begin{array}{c}\text { Cmpd } \\
\#\end{array}$ & Compound & $\begin{array}{c}\mathrm{CAS}^{2} \\
\text { Number }\end{array}$ & $\begin{array}{c}\text { Average } \\
\text { (ppmv) }\end{array}$ & $\begin{array}{c}\text { Standard } \\
\text { Deviation } \\
\text { (ppmv) }\end{array}$ & $\begin{array}{c}\mathrm{RSD}^{4} \\
(\%)\end{array}$ \\
\hline 1 & Ethanenitrile (acetonitrile) & $75-05-8$ & 0.15 & 0.07 & 41 \\
2 & Propanone (acetone) & $67-64-1$ & 0.11 & 0.04 & 41 \\
3 & n-Butanenitrile & $109-74-0$ & 0.090 & 0.021 & 24 \\
4 & n-Heptane & $142-82-5$ & 0.017 & 0.004 & 21 \\
5 & n-Pentanenitrile & $110-59-8$ & 0.016 & 0.003 & 16 \\
6 & 2-Hexanone & $591-78-6$ & 0.011 & 0.001 & 12 \\
7 & 2-Heptanone & $110-43-0$ & 0.014 & 0.002 & 18 \\
8 & n-Undecane & $1120-21-4$ & 0.0039 & 0.0002 & 5 \\
9 & n-Dodecane & $112-40-3$ & 0.0091 & 0.0008 & 9 \\
10 & n-Tridecane & $629-50-5$ & 0.036 & 0.006 & 17 \\
\hline \hline
\end{tabular}

1 Results in this table are quantitative (as defined in Section 4.1).

2 CAS = Chemical Abstract Service.

3 Average of 3, 1-L TST samples.

4 RSD $=$ relative standard deviation. Burnum (1995) specifies the RSD should be less than $25 \%$. 
WHC-SD-WM-ER-506 Rev. 0

Table 4-5

Tank AX-102 Positively Identified Organic Analytes in TST SamplesAnalyses by Oak Ridge National Laboratory'

\begin{tabular}{clcccc}
\hline $\begin{array}{c}\text { Compd } \\
\#\end{array}$ & Compound & $\begin{array}{c}\text { CAS }^{2} \\
\text { Number }\end{array}$ & $\begin{array}{c}\text { Average } \\
\text { (ppmv) }\end{array}$ & $\begin{array}{c}\text { Standard } \\
\text { Deviation } \\
\text { (ppmv) }\end{array}$ & $\begin{array}{c}\text { RSD }^{4} \\
(\%)\end{array}$ \\
\hline 1 & 1,1-Dichloroethene (vinylidene chloride) & $75-35-4$ & 0.0033 & 0.0012 & 37 \\
2 & Propanenitrile & $107-12-0$ & 0.048 & 0.014 & 28 \\
3 & n-Hexane & $110-54-3$ & 0.0047 & 0.0013 & 28 \\
4 & Benzene & $71-43-2$ & 0.0019 & 0.0003 & 16 \\
5 & Toluene & $108-88-3$ & 0.0038 & 0.0007 & 18 \\
6 & n-Octane & $111-65-9$ & 0.0025 & 0.0003 & 13 \\
7 & n-Hexanenitrile & $628-73-9$ & 0.0041 & 0.0008 & 18 \\
8 & n-Nonane & $111-84-2$ & 0.0017 & 0.0003 & 18 \\
9 & n-Heptanenitrile & $629-08-3$ & 0.0029 & 0.0007 & 23 \\
10 & 2-Octanone & $111-13-7$ & 0.0017 & 0.0007 & 40 \\
11 & n-Decane & $124-18-5$ & 0.0021 & 0.0001 & 6 \\
\hline \hline
\end{tabular}

1 Results in this table are not quantitative (as defined in Section 4.1) because measured values in at least 1 of the samples are outside instrument calibration limits.

$2 \mathrm{CAS}=$ Chemical Abstract Service.

3 Average of 3, 1-L TST samples.

4 RSD = relative standard deviation. Burnum (1995) specifies the RSD should be less than $25 \%$. 
WHC-SD-WM-ER-506 Rev. 0

Table 4-6

Tank AX-102 Positively Identified Organic Analytes in TST Samples for which Practical Holding Times were Exceeded -Analyses by Oak Ridge National Laboratory ${ }^{1}$

\begin{tabular}{clcccc}
\hline $\begin{array}{c}\text { Compd } \\
\#\end{array}$ & Compound & $\begin{array}{c}\text { CAS }^{2} \\
\text { Number }\end{array}$ & $\begin{array}{c}\text { Average }^{3} \\
\text { (ppmv) }\end{array}$ & $\begin{array}{c}\text { Standard } \\
\text { Deviation } \\
\text { (ppmv) }\end{array}$ & $\begin{array}{c}\text { RSD }^{4} \\
(\%)\end{array}$ \\
\hline 1 & Butanal $^{5}$ & $123-72-8$ & 0.088 & 0.032 & 36 \\
2 & 1-Butanol & $71-36-3$ & 0.17 & 0.04 & 26 \\
3 & 2-Pentanone & $107-87-9$ & 0.0073 & 0.0017 & 23 \\
\hline \hline
\end{tabular}

1 Practical holding times are defined and discussed in Section 4.1.

$2 \mathrm{CAS}=$ Chemical Abstract Service.

3 Average of 3, 1-L TST samples.

4 RSD = relative standard deviation. Burnum (1995) specifies the RSD should be less than $25 \%$.

5 The concentration of this analyte is quantitatively measured (as defined in Section 4.1).

6 The concentration of this analyte was not quantitatively measured (as defined in Section 4.1), because the measured concentration was outside of the instrumental calibration limits. 
WHC-SD-WM-ER-506 Rev. 0

Table 4-7

Tank AX -102 Comparison of Positively Identified Organic Compounds Analyses by Pacific Northwest Laboratory and Oak Ridge National Laboratory

\begin{tabular}{lcccc}
\hline \hline Compound & $\begin{array}{c}\text { CAS } \\
\text { Number }\end{array}$ & $\begin{array}{c}\text { PNL } \\
\text { SUMMA } \\
\text { Average }^{2} \\
\text { (ppmv) }^{2}\end{array}$ & $\begin{array}{c}\text { PNL TST } \\
\text { Average }^{3} \\
\text { (ppmv) }\end{array}$ & $\begin{array}{c}\text { ORNL TST } \\
\text { Average }^{4} \\
\text { (ppmv) }\end{array}$ \\
\hline \hline Ethanenitrile (acetonitrile) & $75-05-8$ & 0.26 & 0.16 & 0.15 \\
Propanone (acetone) & $67-64-1$ & 0.22 & 0.17 & 0.11 \\
1,1-Dichloroethene & $75-35-4$ & $<0.005$ & $<0.005$ & $0.0033^{5}$ \\
Dichloromethane (methylene chloride) & $75-09-2$ & $<0.005$ & 0.0063 & $<0.0053$ \\
Propanenitrile & $107-12-0$ & 0.045 & 0.075 & $0.048^{5}$ \\
n-Butanenitrile & $109-74-0$ & 0.088 & 0.085 & 0.090 \\
Benzene & $71-43-2$ & $<0.005$ & $<0.005$ & $0.0019^{5}$ \\
n-Heptane & $142-82-5$ & 0.011 & 0.014 & 0.017 \\
Toluene & $108-88-3$ & $<0.005$ & 0.0055 & $0.0038^{5}$ \\
n-Decane & $124-18-5$ & $<0.005$ & $<0.005$ & $0.0021^{5}$ \\
\hline \hline
\end{tabular}

$1 \mathrm{CAS}=$ Chemical Abstract Service.

2 Average of 3 SUMMA $^{\text {TM }}$ sample analyses by PNL.

3 Average of 3 TST sample analyses by PNL.

4 Average of 3, 1-L TST sample analyses by ORNL.

5 This compound was not quantitated in all 3 TST samples. 
WHC-SD-WM-ER-506 Rev. 0

Table 4-8

Tank AX-102 Tentatively Identified Compounds in SUMMA ${ }^{\text {TM }}$ Samples -Analyses by Pacific Northwest Laboratory

\begin{tabular}{|c|c|c|c|c|}
\hline$\underset{\#}{\text { Cmpd }}$ & Compounds & $\begin{array}{c}\text { CAS }^{1} \\
\text { Number }\end{array}$ & $\begin{array}{l}\text { Average }^{2} \\
\left(\mathrm{mg} / \mathrm{m}^{3}\right)\end{array}$ & $\begin{array}{c}\text { Standard } \\
\text { Deviation } \\
\left(\mathrm{mg} / \mathrm{m}^{3}\right)\end{array}$ \\
\hline 1 & Propane & $74-98-6$ & 0.24 & 0.02 \\
\hline 2 & Unknown & & 0.076 & 0.026 \\
\hline 3 & Methanol (methyl alcohol) & $67-56-1$ & 4.0 & 0.4 \\
\hline 4 & n-Butane & $106-97-8$ & 0.28 & 0.03 \\
\hline 5 & Methane, dichlorofluoro- & $75-43-4$ & 0.25 & 0.04 \\
\hline 6 & Ethanol & $64-17-5$ & 0.47 & 0.24 \\
\hline 7 & Butanal & $123-72-8$ & 0.22 & 0.02 \\
\hline 8 & Unknown & & 0.059 & 0.013 \\
\hline 9 & 1-Butanol & $71-36-3$ & 0.39 & 0.03 \\
\hline 10 & Unknown & & 0.14 & 0.01 \\
\hline 11 & Unknown Alkane & & 0.051 & 0.001 \\
\hline 12 & Unknown & & 0.049 & 0.003 \\
\hline 13 & 4-Heptanone & $123-19-3$ & $<0.05$ & -- \\
\hline 14 & 3-Heptanone & $106-35-4$ & 1.2 & 0.2 \\
\hline 15 & 2-Heptanone ${ }^{3}$ & $110-43-0$ & 0.049 & - \\
\hline 16 & Unknown & & 0.042 & 0.011 \\
\hline 17 & Unknown Aldehyde & & 0.071 & 0.013 \\
\hline 18 & Unknown & & 0.16 & 0.01 \\
\hline \multicolumn{3}{|c|}{ Sum of tentatively identified compounds: } & 7.7 & \\
\hline
\end{tabular}

$1 \mathrm{CAS}=$ Chemical Abstract Service.

2 Based on analyses of 3 samples. Values given are estimates.

3 Detected in only 1 sample. 
WHC-SD-WM-ER-506 Rev. 0

Table 4-9

Tank AX-102 Tentatively Identified Compounds in TST Samples -Analyses by Pacific Northwest Laboratory

\begin{tabular}{|c|c|c|c|c|}
\hline$\underset{\#}{\text { Cmpd }}$ & Compounds & $\begin{array}{c}\text { CAS }^{1} \\
\quad \text { Number }\end{array}$ & $\begin{array}{l}\text { Average }{ }^{2} \\
\left(\mathrm{mg} / \mathrm{m}^{3}\right)\end{array}$ & $\begin{array}{c}\text { Standard }^{3} \\
\text { Deviation } \\
\left(\mathrm{mg} / \mathrm{m}^{3}\right)\end{array}$ \\
\hline 1 & Methanol (methyl alcohol) & $67-56-1$ & 0.42 & 0.05 \\
\hline 2 & n-Butane & $106-97-8$ & 0.047 & 0.006 \\
\hline 3 & Ethanol & $64-17-5$ & 0.12 & 0.01 \\
\hline 4 & 1-Propanol & $71-23-8$ & 0.10 & 0.03 \\
\hline 5 & Unknown Ketone & & 0.049 & 0.011 \\
\hline 6 & Butanal & $123-72-8$ & 0.073 & 0.041 \\
\hline 7 & Unknown Aldehyde & & 0.050 & 0.008 \\
\hline 8 & Propylene Glycol & $57-55-6$ & 0.14 & 0.01 \\
\hline 9 & Pentanenitrile & $110-59-8$ & 0.061 & 0.017 \\
\hline 10 & 2-Hexanone ${ }^{4}$ & $591-78-6$ & 0.051 & 0.004 \\
\hline 11 & Heptane, 3-methyl- & $589-81-1$ & 0.079 & 0.003 \\
\hline 12 & Unknown & & 0.035 & 0.018 \\
\hline 13 & Nitric acid, butyl ester & $928-45-0$ & 0.061 & 0.007 \\
\hline 14 & Butane, 1-nitro-5 & $627-05-4$ & 0.049 & - \\
\hline 15 & 3-Heptanone & $106-35-4$ & 1.3 & 0.03 \\
\hline 16 & 3-Heptanol & $589-82-2$ & 0.13 & 0.002 \\
\hline 17 & Butanamide & $541-35-5$ & 0.079 & 0.023 \\
\hline 18 & Unknown & & 0.067 & 0.004 \\
\hline 19 & Unknown & & 0.096 & 0.002 \\
\hline 20 & Hexanal, 2-ethyl- & $123-05-7$ & 0.11 & 0.01 \\
\hline 21 & Unknown & & 0.030 & 0.031 \\
\hline 22 & Unknown & & 0.039 & 0.011 \\
\hline 23 & Unknown & & 0.18 & 0.02 \\
\hline 24 & 1-Hexanol, 2-ethyl- & $104-76-7$ & 0.14 & 0.01 \\
\hline 25 & Unknown Alcohol & & 0.18 & 0.001 \\
\hline 26 & Unknown Ketone & & 0.073 & 0.002 \\
\hline
\end{tabular}


WHC-SD-WM-ER-506 Rev. 0

\begin{tabular}{clccc}
\hline $\begin{array}{c}\text { Cmpd } \\
\#\end{array}$ & Compounds & $\begin{array}{c}\text { CAS }^{1} \\
\text { Number }\end{array}$ & $\begin{array}{c}\text { Average } \\
\left(\mathrm{mg} / \mathrm{m}^{3}\right)\end{array}$ & $\begin{array}{c}\text { Standard } \\
\text { Deviation } \\
\left(\mathrm{mg} / \mathrm{m}^{3}\right)\end{array}$ \\
\hline 27 & n-Dodecane & $112-40-3$ & 0.084 & 0.002 \\
28 & n-Tridecane & $629-50-5$ & 0.22 & 0.003 \\
29 & n-Tetradecane & $629-59-4$ & 0.091 & 0.001 \\
\hline \hline Sum of tentatively identified compounds: & & 4.1 & \\
\hline
\end{tabular}

$1 \mathrm{CAS}=$ Chemical Abstract Service.

2 Based on analyses of 3 TST samples. Values given are estimates. 3 When the analyte was detected in only 2 samples, the entry is the average difference (i.e., their
difference divided by 2 ).

4 Detected in only 2 samples.

5 Detected in only 1 sample. 
Table 4-10

Tank AX-102 Tentatively Identified Organic Compounds in TST Samples Analyses by Oak Ridge National Laboratory

\begin{tabular}{|c|c|c|c|c|}
\hline$\underset{\#}{\text { Cmpd }}$ & Compounds & $\begin{array}{c}\text { CAS }^{1} \\
\text { Number }\end{array}$ & $\begin{array}{l}\text { Average } 2 \\
\left(\mathrm{mg} / \mathrm{m}^{3}\right)\end{array}$ & $\begin{array}{l}\text { Standard } \\
\text { Deviation } \\
\left(\mathrm{mg} / \mathrm{m}^{3}\right)\end{array}$ \\
\hline 1 & Methyl nitrite & $624-91-9$ & 0.027 & 0.029 \\
\hline 2 & Methanol (methyl alcohol) & $67-56-1$ & 0.79 & 0.28 \\
\hline 3 & Mixture & & 0.0085 & 0.0090 \\
\hline 4 & Methane, dichlorofluoro- & $75-43-4$ & 0.038 & 0.015 \\
\hline 5 & Ethanol & $64-17-5$ & 0.13 & 0.05 \\
\hline 6 & Trichloromonofluoromethane & $75-69-4$ & 0.34 & 0.08 \\
\hline 7 & Silane, chlorotrimethyl- & $75-77-4$ & 0.016 & 0.028 \\
\hline 8 & Formamide and others & & 0.0043 & 0.0074 \\
\hline 9 & Mixture & & 0.010 & 0.010 \\
\hline 10 & 1-Propanol & $71-23-8$ & 0.061 & 0.013 \\
\hline 11 & 3-Buten-2-one & $78-94-4$ & 0.029 & 0.008 \\
\hline 12 & 2-Butanone & $78-93-3$ & 0.14 & 0.04 \\
\hline 13 & Nitric acid, ethyl ester & $625-58-1$ & 0.035 & 0.018 \\
\hline 14 & Cyclopropane, butyl- & $930-57-4$ & 0.0022 & 0.0038 \\
\hline 15 & 1,4-Butanediol, dinitrate & $3457-91-8$ & 0.035 & 0.006 \\
\hline 16 & Alkene & & 0.0074 & 0.0068 \\
\hline 17 & Propane, 1-nitro- & $108-03-2$ & 0.021 & 0.010 \\
\hline 18 & Pyrazine & $290-37-9$ & 0.0029 & 0.0051 \\
\hline 19 & Propylene Glycol & $57-55-6$ & 0.053 & 0.038 \\
\hline 20 & Heptane, 3-methyl- & $589-81-1$ & 0.036 & 0.005 \\
\hline 21 & 1-Octene & $111-66-0$ & 0.0024 & 0.0042 \\
\hline 22 & Benzothiazole, 2-phenyl- & $883-93-2$ & 0.0069 & 0.0119 \\
\hline 23 & 3-Hexanone & $589-38-8$ & 0.018 & 0.010 \\
\hline 24 & Cyclopentane, 1,2,3-trimethyl- & $2815-57-8$ & 0.0016 & 0.0027 \\
\hline 25 & 2-Ethyl-5-methylfuran & $1703-52-2$ & 0.0078 & 0.0136 \\
\hline 26 & Hexanal & $66-25-1$ & 0.018 & 0.017 \\
\hline 27 & Acetamide & $60-35-5$ & 0.0056 & 0.0065 \\
\hline
\end{tabular}


WHC-SD-WM-ER-506 Rev. 0

\begin{tabular}{|c|c|c|c|c|}
\hline Cmpd & Compounds & $\begin{array}{c}\mathrm{CAS}^{1} \\
\text { Number }\end{array}$ & $\begin{array}{l}\text { Average } \\
\left(\mathrm{mg} / \mathrm{m}^{3}\right)\end{array}$ & $\begin{array}{l}\text { Standard } \\
\text { Deviation } \\
\left(\mathrm{mg} / \mathrm{m}^{3}\right)\end{array}$ \\
\hline 28 & 2(3H)-Furanone, 5-ethyldihydro- & $695-06-7$ & 0.0018 & 0.0031 \\
\hline 29 & Tetrachloroethylene & $127-18-4$ & 0.13 & 0.01 \\
\hline 30 & Cyclotrisiloxane, hexamethyl- & $541-05-9$ & 0.048 & 0.052 \\
\hline 31 & 1,4-Butanediol, dinitrate & $3457-91-8$ & 0.046 & 0.007 \\
\hline 32 & 3-Hexanone, 5-methyl- & $623-56-3$ & 0.0059 & 0.0052 \\
\hline 33 & Propane, 2-methyl-2-nitro- & $594-70-7$ & 0.051 & 0.016 \\
\hline 34 & Mixture & & 0.0025 & 0.0043 \\
\hline 35 & 7-Oxabicycio[4.1.0]heptane, 1-methyl- & $1713-33-3$ & 0.0071 & 0.0062 \\
\hline 36 & Nonanal & $124-19-6$ & 0.0064 & 0.0058 \\
\hline 37 & 4-Heptanone & $123-19-3$ & 0.086 & 0.009 \\
\hline 38 & Alkylcyclopropane & & 0.0035 & 0.0060 \\
\hline 39 & 3-Hexanone, 2,5-dimethyl- & $1888-57-9$ & 0.033 & 0.014 \\
\hline 40 & 3-Heptanone & $106-35-4$ & 0.98 & 0.10 \\
\hline 41 & 3-Heptanol & $589-82-2$ & 0.092 & 0.011 \\
\hline 42 & Heptanal & $111-71-7$ & 0.0073 & 0.0063 \\
\hline 43 & Furan, 2,3-dihydro-4-(1-methylpropyl)-.(S)- & $34379-54-9$ & 0.0018 & 0.0032 \\
\hline 44 & Pyridine, 2-ethyl- & $100-71-0$ & 0.0072 & 0.0063 \\
\hline 45 & Butyrolactone & $96-48-0$ & 0.012 & 0.002 \\
\hline 46 & Mixture & & 0.0205 & 0.0020 \\
\hline 47 & 3-Hexanone, 4-ethyl- & $6137-12-8$ & 0.0011 & 0.0019 \\
\hline 48 & 2,5-Hexanedione & $110-13-4$ & 0.0026 & 0.0044 \\
\hline 49 & 2,2-Bioxepane & $74793-02-5$ & 0.036 & 0.031 \\
\hline 50 & 3-Hexen-2-oné & $763-93-9$ & 0.016 & 0.028 \\
\hline 51 & 3-Penten-2-one, 4-methyl- & $141-79-7$ & 0.086 & 0.009 \\
\hline 52 & Hexanal, 2-ethyl- & $123-05-7$ & 0.13 & 0.11 \\
\hline 53 & 3-Hepten-2-one, 3-methyl- & $39899-08-6$ & 0.048 & 0.083 \\
\hline 54 & $2(3 \mathrm{H})$-Furanone, dihydro-5-methyl- & $108-29-2$ & 0.044 & 0.006 \\
\hline 55 & Butanamide & $541-35-5$ & 0.0053 & 0.0092 \\
\hline 56 & 3-Hexen-2-one, 5-methyl- & $5166-53-0$ & 0.017 & 0.004 \\
\hline
\end{tabular}


WHC-SD-WM-ER-506 Rev. 0

\begin{tabular}{|c|c|c|c|c|}
\hline Cmpd & Compounds & $\begin{array}{l}\text { CAS }^{1} \\
\text { Number }\end{array}$ & $\begin{array}{l}\text { Average }^{2} \\
\left(\mathrm{mg} / \mathrm{m}^{3}\right)\end{array}$ & $\begin{array}{l}\text { Standard } \\
\text { Deviation } \\
\left(\mathrm{mg} / \mathrm{m}^{3}\right)\end{array}$ \\
\hline 57 & 4-Octanone & $589-63-9$ & 0.0072 & 0.0064 \\
\hline 58 & Cyclohexane, 1-ethyl-4-methyl-, cis- & $4926-78-7$ & 0.0014 & 0.0025 \\
\hline 59 & Cyclotetrasiloxane, octamethyl- & $556-67-2$ & 0.022 & 0.031 \\
\hline 60 & 3-Methyl-4-octanone & 20754-04-5 & 0.012 & 0.011 \\
\hline 61 & 2-Hexenal, 2-ethyl- & $645-62-5$ & 0.017 & 0.004 \\
\hline 62 & 5-Hexen-1-ol & $821-41-0$ & 0.071 & 0.003 \\
\hline 63 & Mixture & & 0.0042 & 0.0048 \\
\hline 64 & Hexane, 2,5-dimethyl- & $592-13-2$ & 0.23 & 0.02 \\
\hline 65 & Pyridine, 5-ethyl-2-methyl- & $104-90-5$ & 0.0018 & 0.0030 \\
\hline 66 & Mixture & & 0.0023 & 0.0040 \\
\hline 67 & 1-Propanol, 2,2-dimethyl-, nitrate & $926-42-1$ & 0.17 & 0.01 \\
\hline 68 & 2(3H)-Furanone, 5-ethyldihydro- & $695-06-7$ & 0.011 & 0.001 \\
\hline 69 & 5-Nonanone & $502-56-7$ & 0.0016 & 0.0028 \\
\hline 70 & Acetophenone and alkene & & 0.022 & 0.002 \\
\hline 71 & Octanenitrile & $124-12-9$ & 0.0029 & 0.0051 \\
\hline 72 & Mixture & & 0.0014 & 0.0025 \\
\hline 73 & 2-Nonanone & $821-55-6$ & 0.0027 & 0.0048 \\
\hline 74 & Nonanal and others & & 0.012 & 0.002 \\
\hline 75 & Alkyl Nitrile & & 0.014 & 0.000 \\
\hline 76 & Nitric acid, pentyl ester & $1002-16-0$ & 0.0016 & 0.0027 \\
\hline 77 & Alkyl Nitrile & & 0.0025 & 0.0044 \\
\hline 78 & $\begin{array}{l}\text { Benzoic acid, 2-[(trimethylsilyl)oxy]-, } \\
\text { trimethylsilyl ester }\end{array}$ & $3789-85-3$ & 0.0071 & 0.0074 \\
\hline 79 & Propanoic acid, 2-methyl-, butyl ester & $97-87-0$ & 0.017 & 0.016 \\
\hline 80 & Decane, 2,2,3-trimethyl- & $62338-09-4$ & 0.014 & 0.001 \\
\hline 81 & 2(3H)-Furanone, dihydro-5-propyl- & $105-21-5$ & 0.0071 & 0.0062 \\
\hline 82 & 5-Undecanone, 2-methyl- & $50639-02-6$ & 0.0016 & 0.0028 \\
\hline 83 & 2,4(3H,5H)-Furandione, 3-methyl- & $1192-51-4$ & 0.018 & 0.003 \\
\hline 84 & 2-Pyrrolidinone and others & & 0.10 & 0.00 \\
\hline
\end{tabular}


WHC-SD-WM-ER-506 Rev. 0

\begin{tabular}{|c|c|c|c|c|}
\hline Cmpd & Compounds & $\begin{array}{l}\mathrm{CAS}^{1} \\
\text { Number }\end{array}$ & $\begin{array}{l}\text { Average } \\
\left(\mathrm{mg} / \mathrm{m}^{3}\right)\end{array}$ & $\begin{array}{l}\text { Standard } \\
\text { Deviation } \\
\left(\mathrm{mg} / \mathrm{m}^{3}\right)\end{array}$ \\
\hline 85 & Alkanal and others & & 0.032 & 0.008 \\
\hline 86 & Alkene & & 0.0017 & 0.0030 \\
\hline 87 & Alkene & & 0.0024 & 0.0042 \\
\hline 88 & Mixture & & 0.0013 & 0.0022 \\
\hline 89 & Mixture & & 0.0011 & 0.0019 \\
\hline 90 & Methenamine & $100-97-0$ & 0.0038 & 0.0066 \\
\hline 91 & 2(3H)-Furanone, dihydro-5-pentyl- & $104-61-0$ & 0.015 & 0.006 \\
\hline 92 & Mixture & & 0.0037 & 0.0064 \\
\hline 93 & Butyl, 2-ethylhexanoate & $68443-63-0$ & 0.0071 & 0.0064 \\
\hline 94 & $\begin{array}{l}\text { Propanedioic acid, [(trimethylsilyl)oxy]-, } \\
\text { bis(trimethylsilyl) ester }\end{array}$ & $27750-45-4$ & 0.0038 & 0.0066 \\
\hline 95 & 6-Dodecanone and others & & 0.0036 & 0.0063 \\
\hline 96 & $2(3 \mathrm{H})-$ Furanone, dihydro-5-pentyl- & $104-61-0$ & 0.0020 & 0.0035 \\
\hline 97 & $\begin{array}{l}\text { 3,6-Dioxa-2,4,5,7-tetrasilaoctane, } \\
2,2,4,4,5,5,7,7 \text {-octamethyl- }\end{array}$ & $4342-25-0$ & 0.021 & 0.003 \\
\hline 98 & Tetradecane & $629-59-4$ & 0.12 & 0.01 \\
\hline 99 & 6-Tridecanone & $22026-12-6$ & 0.0034 & 0.0059 \\
\hline 100 & 5-Tridecanone & $30692-16-1$ & 0.020 & 0.018 \\
\hline 101 & 2(3H)-Furanone, 5-hexyldihydro- & $706-14-9$ & 0.0011 & 0.0018 \\
\hline 102 & 3-Tridecanone & $1534-26-5$ & 0.011 & 0.010 \\
\hline 103 & Pentadecane & $629-62-9$ & 0.010 & 0.012 \\
\hline 104 & 1,1'-Biphenyl, 2-chloro- & $2051-60-7$ & 0.0023 & 0.0040 \\
\hline 105 & Heptasiloxane, hexadecamethyl- & $541-01-5$ & 0.022 & 0.002 \\
\hline 106 & 6-Dodecanone & $6064-27-3$ & 0.0072 & 0.0063 \\
\hline 107 & 3-Tridecanone & $1534-26-5$ & 0.0043 & 0.0075 \\
\hline 108 & 2-Tetradecanone & $2345-27-9$ & 0.0056 & 0.0053 \\
\hline 109 & $\begin{array}{l}\text { Propanoic acid, } \\
\text { 2-methyl-, 1-(1,1-dimethylethyl)-2-methyl-1,3 } \\
\text {-propanediyl ester }\end{array}$ & $74381-40-1$ & 0.0016 & 0.0028 \\
\hline 110 & Benzenesulfonamide, $\mathrm{N}$-butyl- & $3622-84-2$ & 0.18 & 0.13 \\
\hline
\end{tabular}


WHC-SD-WM-ER-506 Rev. 0

\begin{tabular}{|c|c|c|c|}
\hline Cmpd Compounds & $\begin{array}{l}\text { CAS }^{\mathbf{1}} \\
\text { Number }\end{array}$ & $\begin{array}{l}\text { Average } \\
\left(\mathrm{mg} / \mathrm{m}^{3}\right)\end{array}$ & $\begin{array}{c}\text { Standard } \\
\text { Deviation } \\
\left(\mathrm{mg} / \mathrm{m}^{3}\right)\end{array}$ \\
\hline Sum of tentatively identified compounds: & & $\overline{5.0}$ & \\
\hline
\end{tabular}

$1 \mathrm{CAS}=$ Chemical Abstract Service.

3 Average of 3, 1-L TST samples. Values given are estimates. 
WHC-SD-WM-ER-506 ReV. 0

Table 4-11

Tank AX-102 Tentatively Identified Organic Compounds in TST Samples Sorted Alphanumerically by Compound Name Analyses by Oak Ridge National Laboratory

\begin{tabular}{|c|c|c|c|c|}
\hline Cmpd & Compounds & $\begin{array}{l}\mathrm{CAS}^{1} \\
\text { Number }\end{array}$ & $\begin{array}{l}\text { Average } \\
\left(\mathrm{mg} / \mathrm{m}^{3}\right)\end{array}$ & $\begin{array}{c}\text { Standard } \\
\text { Deviation } \\
\left(\mathrm{mg} / \mathrm{m}^{3}\right)\end{array}$ \\
\hline 21 & 1-Octene & $111-66-0$ & 0.0024 & 0.0042 \\
\hline 10 & 1.-Propanol & $71-23-8$ & 0.061 & 0.013 \\
\hline 67 & 1-Propanol, 2,2-dimethyl-, nitrate & $926-42-1$ & 0.17 & 0.01 \\
\hline 104 & 1,1'-Biphenyl, 2-chloro- & $2051-60-7$ & 0.0023 & 0.0040 \\
\hline 31 & 1,4-Butanediol, dinitrate & $3457-91-8$ & 0.046 & 0.007 \\
\hline 15 & 1,4-Butanediol, dinitrate & $3457-91-8$ & 0.035 & 0.006 \\
\hline 73 & 2-Nonanone & $821-55-6$ & 0.0027 & 0.0048 \\
\hline 84 & 2-Pyrrolidinone and others & & 0.10 & 0.00 \\
\hline 12 & 2-Butanone & $78-93-3$ & 0.14 & 0.04 \\
\hline 61 & 2-Hexenal, 2-ethyl- & $645-62-5$ & 0.017 & 0.004 \\
\hline 108 & 2-Tetradecanone & $2345-27-9$ & 0.0056 & 0.0053 \\
\hline 25 & 2-Ethyl-5-methylfuran & $1703-52-2$ & 0.0078 & 0.0136 \\
\hline 49 & 2,2'-Bioxepane & $74793-02-5$ & 0.036 & 0.031 \\
\hline 48 & 2,5-Hexanedione & $110-13-4$ & 0.0026 & 0.0044 \\
\hline 83 & 2,4(3H,5H)-Furandione, 3-methyl- & $1192-51-4$ & 0.018 & 0.003 \\
\hline 96 & $2(3 \mathrm{H})$-Furanone, difhydro-5-pentyl- & $104-61-0$ & 0.0020 & 0.0035 \\
\hline 68 & 2(3H)-Furanone, 5-ethyldihydro- & $695-06-7$ & 0.011 & 0.001 \\
\hline 54 & 2(3H)-Furanone, dihydro-5-methyl- & $108-29-2$ & 0.044 & 0.006 \\
\hline 81 & 2(3H)-Furanone, dihydro-5-propyl- & $105-21-5$ & 0.0071 & 0.0062 \\
\hline 101 & 2(3H)-Furanone, 5-hexyldihydro- & $706-14-9$ & 0.0011 & 0.0018 \\
\hline 28 & $2(3 \mathrm{H})$-Furanone, 5-ethyldihydro- & $695-06-7$ & 0.0018 & 0.0031 \\
\hline 91 & $2(3 \mathrm{H})$-Furanone, dihydro-5-pentyl- & $104-61-0$ & 0.015 & 0.006 \\
\hline 11 & 3-Buten-2-one & $78-94-4$ & 0.029 & 0.008 \\
\hline 107 & 3-Tridecanone & $1534-26-5$ & 0.0043 & 0.0075 \\
\hline 102 & 3-Tridecanone & $1534-26-5$ & 0.011 & 0.010 \\
\hline 60 & 3-Methyl-4-octanone & 20754-04-5 & 0.012 & 0.011 \\
\hline
\end{tabular}


WHC-SD-WM-ER-506 Rev. 0

\begin{tabular}{|c|c|c|c|c|}
\hline Cmpd & Compounds & $\begin{array}{l}\text { CAS }^{1} \\
\text { Number }\end{array}$ & $\begin{array}{l}\text { Average }^{2} \\
\left(\mathrm{mg} / \mathrm{m}^{3}\right)\end{array}$ & $\begin{array}{c}\text { Standard } \\
\text { Deviation } \\
\left(\mathrm{mg} / \mathrm{m}^{3}\right) \\
\end{array}$ \\
\hline 23 & 3-Hexanone & $589-38-8$ & 0.018 & 0.010 \\
\hline 51 & 3-Penten-2-one, 4-methyl- & $141-79-7$ & 0.086 & 0.009 \\
\hline 32 & 3-Hexanone, 5-methyl- & $623-56-3$ & 0.0059 & 0.0052 \\
\hline 47 & 3-Hexanone, 4-ethyl- & $6137-12-8$ & 0.0011 & 0.0019 \\
\hline 53 & 3-Hepten-2-one, 3-methyl- & $39899-08-6$ & 0.048 & 0.083 \\
\hline 56 & 3-Hexen-2-one, 5-methyl- & $5166-53-0$ & 0.017 & 0.004 \\
\hline 50 & 3-Hexen-2-one & $763-93-9$ & 0.016 & 0.028 \\
\hline 41 & 3-Heptanol & $589-82-2$ & 0.092 & 0.011 \\
\hline 40 & 3-Heptanone & $106-35-4$ & 0.98 & 0.10 \\
\hline 39 & 3-Hexanone, 2,5-dimethyl- & $1888-57-9$ & 0.033 & 0.014 \\
\hline 97 & $\begin{array}{l}\text { 3,6-Dioxa-2,4,5,7-tetrasilaoctane, } \\
2,2,4,4,5,5,7,7 \text {-octamethyl- }\end{array}$ & $4342-25-0$ & 0.021 & 0.003 \\
\hline 37 & 4-Heptanone & $123-19-3$ & 0.086 & 0.009 \\
\hline 57 & 4-Octanone & $589-63-9$ & 0.0072 & 0.0064 \\
\hline 82 & 5-Undecanone, 2-methyl- & $50639-02-6$ & 0.0016 & 0.0028 \\
\hline 62 & 5-Hexen-1-ol & $821-41-0$ & 0.071 & 0.003 \\
\hline 100 & 5-Tridecanone & $30692-16-1$ & 0.020 & 0.018 \\
\hline 69 & 5-Nonanone & $502-56-7$ & 0.0016 & 0.0028 \\
\hline 95 & 6-Dodecanone and others & & 0.0036 & 0.0063 \\
\hline 106 & 6-Dodecanone & $6064-27-3$ & 0.0072 & 0.0063 \\
\hline 99 & 6-Tridecanone & $22026-12-6$ & 0.0034 & 0.0059 \\
\hline 35 & 7-Oxabicyclo[4.1.0]heptane, 1-methyl- & $1713-33-3$ & 0.0071 & 0.0062 \\
\hline 27 & Acetamide & $60-35-5$ & 0.0056 & 0.0065 \\
\hline 70 & Acetophenone and alkene & & 0.022 & 0.002 \\
\hline 85 & Alkanal and others & & 0.032 & 0.008 \\
\hline 16 & Alkene & & 0.0074 & 0.0068 \\
\hline 86 & Alkene & & 0.0017 & 0.0030 \\
\hline 87 & Alkene & & 0.0024 & 0.0042 \\
\hline 75 & Alkyl Nitrile & & 0.014 & 0.000 \\
\hline
\end{tabular}


WHC-SD-WM-ER-506 REV. 0

\begin{tabular}{|c|c|c|c|c|}
\hline Cmpd & Compounds & $\begin{array}{c}\text { CAS }^{1} \\
\text { Number }\end{array}$ & $\begin{array}{l}\text { Average } \\
\left(\mathrm{mg} / \mathrm{m}^{3}\right)\end{array}$ & $\begin{array}{l}\text { Standard } \\
\text { Deviation } \\
\left(\mathrm{mg} / \mathrm{m}^{3}\right)\end{array}$ \\
\hline 77 & Alkyl Nitrile & & 0.0025 & 0.0044 \\
\hline 38 & Alkylcyclopropane & & 0.0035 & 0.0060 \\
\hline 110 & Benzenesulfonamide, N-butyl- & $3622-84-2$ & 0.18 & 0.13 \\
\hline 78 & $\begin{array}{l}\text { Benzoic acid, 2-[(trimethylsilyl)oxy]-, } \\
\text { trimethylsilyl ester }\end{array}$ & $3789-85-3$ & 0.0071 & 0.0074 \\
\hline 22 & Benzothiazole, 2-phenyl- & $883-93-2$ & 0.0069 & 0.0119 \\
\hline 55 & Butanamide & $541-35-5$ & 0.0053 & 0.0092 \\
\hline 93 & Butyl, 2-ethylhexanoate & $68443-63-0$ & 0.0071 & 0.0064 \\
\hline 45 & Butyrolactone & $96-48-0$ & 0.012 & 0.002 \\
\hline 58 & Cyclohexane, 1-ethyl-4-methyl-, cis- & $4926-78-7$ & 0.0014 & 0.0025 \\
\hline 24 & Cyclopentane, 1,2,3-trimethyl- & $2815-57-8$ & 0.0016 & 0.0027 \\
\hline 14 & Cyclopropane, butyl- & $930-57-4$ & 0.0022 & 0.0038 \\
\hline 59 & Cyclotetrasiloxane, octamethyl- & $556-67-2$ & 0.022 & 0.031 \\
\hline 30 & Cyciotrisiloxane, hexamethyl- & $541-05-9$ & 0.048 & 0.052 \\
\hline 80 & Decane, 2,2,3-trimethyl- & $62338-09-4$ & 0.014 & 0.001 \\
\hline 5 & Ethanol & $64-17-5$ & 0.13 & 0.05 \\
\hline 8 & Formamide and others & & 0.0043 & 0.0074 \\
\hline 43 & Furan, 2,3-dihydro-4-(1-methylpropyl)-,(S)- & $34379-54-9$ & 0.0018 & 0.0032 \\
\hline 42 & Heptanal & $111-71-7$ & 0.0073 & 0.0063 \\
\hline 20 & Heptane, 3-methyl- & $589-81-1$ & 0.036 & 0.005 \\
\hline 105 & Heptasiloxane, hexadecamethyl- & $541-01-5$ & 0.022 & 0.002 \\
\hline 26 & Hexanal & $66-25-1$ & 0.018 & 0.017 \\
\hline 52 & Hexanal, 2-ethyl- & $123-05-7$ & 0.13 & 0.11 \\
\hline 64 & Hexane, 2,5-dimethyl- & $592-13-2$ & 0.23 & 0.02 \\
\hline 4 & Methane, dichlorofluoro- & $75-43-4$ & 0.038 & 0.015 \\
\hline 2 & Methanol (methyl alcohol) & $67-56-1$ & 0.79 & 0.28 \\
\hline 90 & Methenamine & $100-97-0$ & 0.0038 & 0.0066 \\
\hline 1 & Methyl nitrite & $624-91-9$ & 0.027 & 0.029 \\
\hline 3 & Mixture & & 0.0085 & 0.0090 \\
\hline
\end{tabular}


WHC-SD-WM-ER-506 Rev. 0

\begin{tabular}{|c|c|c|c|c|}
\hline$\underset{\#}{\text { Cmpd }}$ & Compounds & $\begin{array}{l}\text { CAS }^{1} \\
\text { Number }\end{array}$ & $\begin{array}{l}\text { Average } \\
\left(\mathrm{mg} / \mathrm{m}^{3}\right)\end{array}$ & $\begin{array}{l}\text { Standard } \\
\text { Deviation } \\
\left(\mathrm{mg} / \mathrm{m}^{3}\right)\end{array}$ \\
\hline 34 & Mixture & & 0.0025 & 0.0043 \\
\hline 46 & Mixture & & 0.0205 & 0.0020 \\
\hline 63 & Mixture & '. & 0.0042 & 0.0048 \\
\hline 66 & Mixture & & 0.0023 & 0.0040 \\
\hline 72 & Mixture & & 0.0014 & 0.0025 \\
\hline 88 & Mixture & & 0.0013 & 0.0022 \\
\hline 89 & Mixture & & 0.0011 & 0.0019 \\
\hline 9 & Mixture & & 0.010 & 0.010 \\
\hline 92 & Mixture & & 0.0037 & 0.0064 \\
\hline 13 & Nitric acid, ethyl ester & $625-58-1$ & 0.035 & 0.018 \\
\hline 76 & Nitric acid, pentyl ester & $1002-16-0$ & 0.0016 & 0.0027 \\
\hline 36 & Nonanal & $124-19-6$ & 0.0064 & 0.0058 \\
\hline 74 & Nonanal and others & & 0.012 & 0.002 \\
\hline 71 & Octanenitrile & $124-12-9$ & 0.0029 & 0.0051 \\
\hline 103 & Pentadecane & $629-62-9$ & 0.010 & 0.012 \\
\hline 17 & Propane, 1-nitro- & $108-03-2$ & 0.021 & 0.010 \\
\hline 33 & Propane, 2-methyl-2-nitro- & $594-70-7$ & 0.051 & 0.016 \\
\hline 94 & $\begin{array}{l}\text { Propanedioic acid, [(trimethylsilyl)oxy\}-, } \\
\text { bis(trimethylsilyl) ester }\end{array}$ & $27750-45-4$ & 0.0038 & 0.0066 \\
\hline 109 & $\begin{array}{l}\text { Propanoic acid, } \\
\text { 2-methyl-11-(1,1-dimethylethyl)-2-methyl-1,3 } \\
\text {-propanediyl ester }\end{array}$ & $74381-40-1$ & 0.0016 & 0.0028 \\
\hline 79 & Propanoic acid, 2-methyl-, butyl ester & $97-87-0$ & 0.017 & 0.016 \\
\hline 19 & Propylene Glycol & $57-55-6$ & 0.053 & 0.038 \\
\hline 18 & Pyrazine & $290-37-9$ & 0.0029 & 0.0051 \\
\hline 44 & Pyridine, 2-ethyl- & $100-71-0$ & 0.0072 & 0.0063 \\
\hline 65 & Pyridine, 5-ethyl-2-methyl- & $104-90-5$ & 0.0018 & 0.0030 \\
\hline 7 & Silane, chlorotrimethyl- & $75-77-4$ & 0.016 & 0.028 \\
\hline 29 & Tetrachloroethylene & $127-18-4$ & 0.13 & 0.01 \\
\hline 98 & Tetradecane & $629-59-4$ & 0.12 & 0.01 \\
\hline
\end{tabular}


WHC-SD-WM-ER-506 Rev. 0

\begin{tabular}{llccc}
\hline $\begin{array}{c}\text { Cmpd } \\
\#\end{array}$ & Compounds & $\begin{array}{c}\text { CAS } \\
\text { Number }\end{array}$ & $\begin{array}{c}\text { Average } \\
\left(\mathrm{mg} / \mathrm{m}^{3}\right)\end{array}$ & $\begin{array}{c}\text { Standard } \\
\text { Deviation } \\
\left(\mathrm{mg} / \mathrm{m}^{3}\right)\end{array}$ \\
\hline 6 & Trichloromonofluoromethane & $75-69-4$ & 0.34 & 0.08 \\
\hline
\end{tabular}

$1 \mathrm{CAS}=$ Chemical Abstract Service.

3 Average of 3, 1-L TST samples. Values given are estimates. 
WHC-SD-WM-ER-506 Rev. 0

Table 4-12

Tank AX-102 Tentatively Identified Organic Compounds in TST Samples Sorted in Order of Decreasing Estimated Concentrations Analyses by Oak Ridge National Laboratory

\begin{tabular}{|c|c|c|c|c|}
\hline Cmpd\# & Compounds & $\begin{array}{c}\text { CAS }^{1} \\
\text { Number }\end{array}$ & $\begin{array}{l}\text { Average }^{2} \\
\left(\mathrm{mg} / \mathrm{m}^{3}\right)\end{array}$ & $\begin{array}{l}\text { Standard } \\
\text { Deviation } \\
\left(\mathrm{mg} / \mathrm{m}^{3}\right)\end{array}$ \\
\hline 40 & 3-Heptanone & $106-35-4$ & 0.98 & 0.10 \\
\hline 2 & Methanol (methyl alcohol) & $67-56-1$ & 0.79 & 0.28 \\
\hline 6 & Trichloromonofluoromethane & $75-69-4$ & 0.34 & 0.08 \\
\hline 64 & Hexane, 2,5-dimethyl- & $592-13-2$ & 0.23 & 0.02 \\
\hline 110 & Benzenesulfonamide, N-butyl- & $3622-84-2$ & 0.18 & 0.13 \\
\hline 67 & 1-Propanol, 2,2-dimethyl-, nitrate & $926-42-1$ & 0.17 & 0.01 \\
\hline 12 & 2-Butanone & $78-93-3$ & 0.14 & 0.04 \\
\hline 29 & Tetrachloroethylene & $127-18-4$ & 0.13 & 0.01 \\
\hline 5 & Ethanol & $64-17-5$ & 0.13 & 0.05 \\
\hline 52 & Hexanal, 2-ethyl- & $123-05-7$ & 0.13 & 0.11 \\
\hline 98 & Tetradecane & $629-59-4$ & 0.12 & 0.01 \\
\hline 84 & 2-Pyrrolidinone and others & & 0.10 & 0.00 \\
\hline 41 & 3-Heptanol & $589-82-2$ & 0.092 & 0.011 \\
\hline 37 & 4-Heptanone & $123-19-3$ & 0.086 & 0.009 \\
\hline 51 & 3-Penten-2-one, 4-methyl- & $141-79-7$ & 0.086 & 0.009 \\
\hline 62 & 5-Hexen-1-ol & $821-41-0$ & 0.071 & 0.003 \\
\hline 10 & 1-Propanol & $71-23-8$ & 0.061 & 0.013 \\
\hline 19 & Propylene Glycol & $57-55-6$ & 0.053 & 0.038 \\
\hline 33 & Propane, 2-methyl-2-nitro- & $594-70-7$ & 0.051 & 0.016 \\
\hline 30 & Cyclotrisiloxane, hexamethyl- & $541-05-9$ & 0.048 & 0.052 \\
\hline 53 & 3-Hepten-2-one, 3-methyl- & $39899-08-6$ & 0.048 & 0.083 \\
\hline 31 & 1,4-Butanediol, dinitrate & $3457-91-8$ & 0.046 & 0.007 \\
\hline 54 & 2(3H)-Furanone, dihydro-5-methyl- & $108-29-2$ & 0.044 & 0.006 \\
\hline 4 & Methane, dichlorofluoro- & $75-43-4$ & 0.038 & 0.015 \\
\hline 49 & 2,2'-Bioxepane & $74793-02-5$ & 0.036 & 0.031 \\
\hline 20 & Heptane, 3-methyl- & $589-81-1$ & 0.036 & 0.005 \\
\hline
\end{tabular}


WHC-SD-WM-ER-506 Rev. 0

\begin{tabular}{|c|c|c|c|c|}
\hline Cmpd\# & Compounds & $\begin{array}{l}\text { CAS }^{1} \\
\text { Number }\end{array}$ & $\begin{array}{l}\text { Average }{ }^{2} \\
\left(\mathrm{mg} / \mathrm{m}^{3}\right)\end{array}$ & $\begin{array}{l}\text { Standard } \\
\text { Deviation } \\
\left(\mathrm{mg} / \mathrm{m}^{3}\right) \\
\end{array}$ \\
\hline 13 & Nitric acid, ethyl ester & $625-58-1$ & 0.035 & 0.018 \\
\hline 15 & 1,4-Butanediol, dinitrate & $3457-91-8$ & 0.035 & 0.006 \\
\hline 39 & 3-Hexanone, 2,5-dimethyl- & $1888-57-9$ & 0.033 & 0.014 \\
\hline 85 & Alkanal and others & & 0.032 & 0.008 \\
\hline 11 & 3-Buten-2-one & $78-94-4$ & 0.029 & 0.008 \\
\hline 1 & Methyl nitrite & $624-91-9$ & 0.027 & 0.029 \\
\hline 59 & Cyclotetrasiloxane, octamethyl- & $556-67-2$ & 0.022 & 0.031 \\
\hline 70 & Acetophenone and alkene & & 0.022 & 0.002 \\
\hline 105 & Heptasiloxane, hexadecamethyl- & $541-01-5$ & 0.022 & 0.002 \\
\hline 97 & $\begin{array}{l}\text { 3,6-Dioxa-2,4,5,7-tetrasilaoctane, } \\
2,2,4,4,5,5,7,7 \text {-octamethyl- }\end{array}$ & $4342-25-0$ & 0.021 & 0.003 \\
\hline 17 & Propane, 1-nitro- & $108-03-2$ & 0.021 & 0.010 \\
\hline 46 & Mixture & & 0.0205 & 0.0020 \\
\hline 100 & 5-Tridecanone & $30692-16-1$ & 0.020 & 0.018 \\
\hline 26 & Hexanal & $66-25-1$ & 0.018 & 0.017 \\
\hline 83 & 2,4(3H,5H)-Furandione, 3-methyl- & $1192-51-4$ & 0.018 & 0.003 \\
\hline 23 & 3-Hexanone & $589-38-8$ & 0.018 & 0.010 \\
\hline 61 & 2-Hexenal, 2-ethyl- & $645-62-5$ & 0.017 & 0.004 \\
\hline 56 & 3-Hexen-2-one, 5-methyl- & $5166-53-0$ & 0.017 & 0.004 \\
\hline 79 & Propanoic acid, 2-methyl-, butyl ester & $97-87-0$ & 0.017 & 0.016 \\
\hline 50 & 3-Hexen-2-one & $763-93-9$ & 0.016 & 0.028 \\
\hline 7 & Silane, chlorotrimethyl- & $75-77-4$ & 0.016 & 0.028 \\
\hline 91 & 2(3H)-Furanone, dihydro-5-pentyl- & $104-61-0$ & 0.015 & 0.006 \\
\hline 75 & Alkyl Nitrile & & 0.014 & 0.000 \\
\hline 80 & Decane, 2,2,3-trimethyl- & $62338-09-4$ & 0.014 & 0.001 \\
\hline 45 & Butyrolactone & $96-48-0$ & 0.012 & 0.002 \\
\hline 74 & Nonanal and others & & 0.012 & 0.002 \\
\hline 60 & 3-Methyl-4-octanone & $20754-04-5$ & 0.012 & 0.011 \\
\hline 68 & 2(3H)-Furanone, 5-ethyldihydro- & $695-06-7$ & 0.011 & 0.001 \\
\hline
\end{tabular}


WHC-SD-WM-ER-506 Rev. 0

\begin{tabular}{|c|c|c|c|c|}
\hline Cmpd\# & Compounds & $\begin{array}{l}\text { CAS }^{1} \\
\text { Number }\end{array}$ & $\begin{array}{l}\text { Average } \\
\left(\mathrm{mg} / \mathrm{m}^{3}\right)\end{array}$ & $\begin{array}{c}\text { Standard } \\
\text { Deviation } \\
\left(\mathrm{mg} / \mathrm{m}^{3}\right) \\
\end{array}$ \\
\hline 102 & 3-Tridecanone & $1534-26-5$ & 0.011 & 0.010 \\
\hline 9 & Mixture & & 0.010 & 0.010 \\
\hline 103 & Pentadecane & $629-62-9$ & 0.010 & 0.012 \\
\hline 3 & Mixture & & 0.0085 & 0.0090 \\
\hline 25 & 2-Ethyl-5-methylfuran & $1703-52-2$ & 0.0078 & 0.0136 \\
\hline 16 & Alkene & & 0.0074 & 0.0068 \\
\hline 42 & Heptanal & $111-71-7$ & 0.0073 & 0.0063 \\
\hline 44 & Pyridine, 2-ethyl- & $100-71-0$ & 0.0072 & 0.0063 \\
\hline 57 & 4-Octanone & $589-63-9$ & 0.0072 & 0.0064 \\
\hline 106 & 6-Dodecanone & $6064-27-3$ & 0.0072 & 0.0063 \\
\hline 81 & 2(3H)-Furanone, dihydro-5-propyl- & $105-21-5$ & 0.0071 & 0.0062 \\
\hline 93 & Butyl, 2-ethylhexanoate & $68443-63-0$ & 0.0071 & 0.0064 \\
\hline 78 & $\begin{array}{l}\text { Benzoic acid, 2-[(trimethylsilyl)oxy]-, } \\
\text { trimethylsilyl ester }\end{array}$ & $3789-85-3$ & 0.0071 & 0.0074 \\
\hline 35 & 7-Oxabicyclo[4.1.0]heptane, 1-methyl- & $1713-33-3$ & 0.0071 & 0.0062 \\
\hline 22 & Benzothiazole, 2-phenyl- & $883-93-2$ & 0.0069 & 0.0119 \\
\hline 36 & Nonanal & $124-19-6$ & 0.0064 & 0.0058 \\
\hline 32 & 3-Hexanone, 5-methyl- & $623-56-3$ & 0.0059 & 0.0052 \\
\hline 27 & Acetamide & $60-35-5$ & 0.0056 & 0.0065 \\
\hline 108 & 2-Tetradecanone & $2345-27-9$ & 0.0056 & 0.0053 \\
\hline 55 & Butanamide & $541-35-5$ & 0.0053 & 0.0092 \\
\hline 8 & Formamide and others & & 0.0043 & 0.0074 \\
\hline 107 & 3-Tridecanone & $1534-26-5$ & 0.0043 & 0.0075 \\
\hline 63 & Mixture & & 0.0042 & 0.0048 \\
\hline 94 & $\begin{array}{l}\text { Propanedioic acid, [(trimethyisilyl)oxy]-, } \\
\text { bis(trimethylsilyl) ester }\end{array}$ & $27750-45-4$ & 0.0038 & 0.0066 \\
\hline 90 & Methenaminie & $100-97-0$ & 0.0038 & 0.0066 \\
\hline 92 & Mixture & & 0.0037 & 0.0064 \\
\hline 95 & 6-Dodecanone and others & & 0.0036 & 0.0063 \\
\hline
\end{tabular}


WHC-SD-WM-ER-506 Rev. 0

\begin{tabular}{|c|c|c|c|c|}
\hline Cmpd\# & Compounds & $\begin{array}{l}\text { CAS }^{1} \\
\text { Number }\end{array}$ & $\begin{array}{c}\text { Average }^{2} \\
\left(\mathrm{mg} / \mathrm{m}^{3}\right)\end{array}$ & $\begin{array}{l}\text { Standard } \\
\text { Deviation } \\
\left(\mathrm{mg} / \mathrm{m}^{3}\right) \\
\end{array}$ \\
\hline 38 & Alkylcyclopropane & & 0.0035 & 0.0060 \\
\hline 99 & 6-Tridecanone & $22026-12-6$ & 0.0034 & 0.0059 \\
\hline 18 & Pyrazine & $290-37-9$ & 0.0029 & 0.0051 \\
\hline 71 & Octanenitrile & $124-12-9$ & 0.0029 & 0.0051 \\
\hline 73 & 2-Nonanone & $821-55-6$ & 0.0027 & 0.0048 \\
\hline 48 & 2,5-Hexanedione & $110-13-4$ & 0.0026 & 0.0044 \\
\hline 34 & Mixture & & 0.0025 & 0.0043 \\
\hline 77 & Alkyl Nitrile & & 0.0025 & 0.0044 \\
\hline 87 & Alkene & & 0.0024 & 0.0042 \\
\hline 21 & 1-Octene & $111-66-0$ & 0.0024 & 0.0042 \\
\hline 66 & Mixture & & 0.0023 & 0.0040 \\
\hline 104 & 1,1'-Biphenyl, 2-chloro- & $2051-60-7$ & 0.0023 & 0.0040 \\
\hline 14 & Cyclopropane, butyl- & $930-57-4$ & 0.0022 & 0.0038 \\
\hline 96 & 2(3H)-Furanone, dihydro-5-pentyl- & $104-61-0$ & 0.0020 & 0.0035 \\
\hline 65 & Pyridine, 5-ethyl-2-methyl- & $104-90-5$ & 0.0018 & 0.0030 \\
\hline 28 & 2(3H)-Furanone, 5-ethyldihydro- & $695-06-7$ & 0.0018 & 0.0031 \\
\hline 43 & Furan, 2,3-dihydro-4-(1-methylpropyl)-,(S)- & $34379-54-9$ & 0.0018 & 0.0032 \\
\hline 86 & Alkene & & 0.0017 & 0.0030 \\
\hline 109 & $\begin{array}{l}\text { Propanoic acid, } \\
\text { 2-methyl-, 1-(1,1-dimethylethyl)-2-methyl-1, } \\
\text { 3-propanediyl ester }\end{array}$ & $74381-40-1$ & 0.0016 & 0.0028 \\
\hline 24 & Cyclopentane, 1,2,3-trimethyl- & $2815-57-8$ & 0.0016 & 0.0027 \\
\hline 69 & 5-Nonanone & $502-56-7$ & 0.0016 & 0.0028 \\
\hline 82 & 5-Undecanone, 2-methyl- & $50639-02-6$ & 0.0016 & 0.0028 \\
\hline 76 & Nitric acid, pentyl ester & $1002-16-0$ & 0.0016 & 0.0027 \\
\hline 58 & Cyclohexane, 1-ethyl-4-methyl-, cis- & $4926-78-7$ & 0.0014 & 0.0025 \\
\hline 72 & Mixture & & 0.0014 & 0.0025 \\
\hline 88 & Mixture & & 0.0013 & 0.0022 \\
\hline 47 & 3-Hexanone, 4-ethyl- & $6137-12-8$ & 0.0011 & 0.0019 \\
\hline
\end{tabular}


WHC-SD-WM-ER-506 Rev. 0

\begin{tabular}{clccc}
\hline \hline Cmpd \# Compounds & $\begin{array}{c}\mathrm{CAS}^{1} \\
\text { Number }\end{array}$ & $\begin{array}{c}\text { Average }^{2} \\
\left(\mathrm{mg} / \mathrm{m}^{3}\right)\end{array}$ & $\begin{array}{c}\text { Standard } \\
\text { Deviation } \\
\left(\mathrm{mg} / \mathrm{m}^{3}\right)\end{array}$ \\
\hline \hline 89 & Mixture & & 0.0011 & $0.0019^{\prime}$ \\
101 & $2(3 \mathrm{H})$-Furanone, 5-hexyldihydro- & $706-14-9$ & 0.0011 & 0.0018 \\
\hline \hline
\end{tabular}

$1 \mathrm{CAS}=$ Chemical Abstract Service.

3 Average of $3,1-L$ TST samples. Values given are estimates.

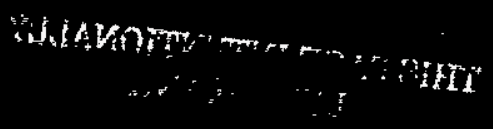


THIIS PAGE INTENTIONAWTI

IDEFT BLANK 